\title{
What Are the Favorable Large-Scale Environments for the Highest-Flash-Rate Thunderstorms on Earth?
}

\author{
Nana LiU, Chuntao LiU, and BaOHua Chen \\ Department of Physical and Environmental Sciences, Texas A\&M University-Corpus Christi, Corpus Christi, Texas \\ EDWARD ZIPSER \\ Department of Atmospheric Sciences, University of Utah, Salt Lake City, Utah
}

(Manuscript received 30 August 2019, in final form 24 February 2020)

\begin{abstract}
A 16-yr Tropical Rainfall Measuring Mission (TRMM) convective feature (CF) dataset and ERAInterim data are used to understand the favorable thermodynamic and kinematic environments for highflash-rate thunderstorms globally as well as regionally. We find that intense thunderstorms, defined as having more than 50 lightning flashes within a CF during the $\sim 90$-s TRMM overpassing time share a few common thermodynamic features over various regions. These include large convective available potential energy ( $>1000 \mathrm{~J} \mathrm{~kg}^{-1}$ ), small to moderate convection inhibition (CIN), and abundant moisture convergence associated with low-level warm advection. However, each region has its own specific features. Generally, thunderstorms with high lightning flash rates have greater CAPE and wind shear than those with low flash rates, but the differences are much smaller in tropical regions than in subtropical regions. The magnitude of the low- to midtropospheric wind shear is greater over the subtropical regions, including the south-central United States, Argentina, and southwest of the Himalayas, than tropical regions, including central Africa, Colombia, and northwest Mexico, with the exception of Sahel region. Relatively, favorable environments of high-flash-rate thunderstorms in the tropical regions are characterized by higher CAPE, lower CIN, and weaker wind shear compared to the high-flash-rate thunderstorms in the subtropical regions, which have a moderate CAPE and CIN, and stronger low to midtropospheric wind shear.
\end{abstract}

\section{Introduction}

Even in their rarity, intense convective phenomena often present a significant threat to life and property. Knowing where there is a high potential of intense thunderstorms could improve weather forecasting and help the public to be better prepared for such events (Brooks et al. 2003). Favorable conditions for convection are proposed in past studies, such as conditional instability, abundant moisture in low-level troposphere, dynamical lifting, and strong wind shear between lower and upper levels (e.g., Fulks 1951; Miller 1972). Later case studies have revealed that both mesoscale and/or synoptic-scale processes contribute to initial lifting prior to thunderstorms, and are usually critical in storm initiation (e.g., Carlson et al. 1983; Cotton et al. 1983; Doswell 1984; Rockwood and Maddox 1988).

\footnotetext{
Corresponding author: Nana Liu, nliu@islander.tamucc.edu
}

Once storms are initiated, wind shear is believed to be particularly important in influencing storm severity and longevity (e.g., Weisman and Klemp 1982; Schoenberg Ferrier et al. 1996; Takemi 2007).

Despite a significant amount of research to date on the mechanisms of intense convection, the majority of data collected on those events are from the United States (e.g., Cotton et al. 1983; Carey and Rutledge 1996; Gallo et al. 2012) and some case studies over specific regions, such as the Himalayas (Barros and Lang 2003; Rasmussen and Houze 2012), Brazil (Chaves and Cavalcanti 2001; Pinto et al. 2004), west Africa (Taylor et al. 2010; Cetrone and Houze 2011), and Australia (Bringi et al. 1996; May 1996). Comprehensive knowledge of intense thunderstorms over underdeveloped regions is still inadequate. In many sparsely populated and remote regions, records or reporting of intense thunderstorms are limited and only a few countries have official systems for these reports. 
Besides limited availability of reports, changes through time and a lack of uniformity in standards for data collection among different countries make comparisons over different regions difficult.

Data from satellites offer one possible approach to solving the problem of different data standards, owing to their large spatial-temporal and near-uniform coverage. The Tropical Rainfall Measuring Mission (TRMM; Kummerow et al. 1998) was a satellite that become a useful tool in the effort to explore intense convection across the tropics and subtropics since its launch (Liu and Zipser 2005; Zipser et al. 2006; Houze et al. 2015). Recently, the Global Precipitation Measurement (GPM) Core Observatory satellite (Hou et al. 2014) and the International Space Station Lightning Imaging Sensor (ISS/LIS; Blakeslee and Koshak 2016) have extended the potential for studies of precipitation and convection to the middle and high latitudes (e.g., Liu and Zipser 2015; Liu and Liu 2016).

With the help of satellite missions, we get a more realistic picture of the worldwide distribution of thunderstorms. The wealth of satellite observations provides opportunities to explore intense thunderstorms globally. A number of studies have revealed that continental convective storms often have more intense convection and exhibit a strong preference over specific regions, such as in the plains area downstream of major mountains (Spencer and Santek 1985; Orville and Henderson 1986; Alcala and Dessler 2002; Liu et al. 2012). Therefore, these favorable regions are of great interest to both educators and researchers, such as South Asia (Houze et al. 2007; Romatschke et al. 2010; Romatschke and Houze 2011), South America (Seluchi and Marengo 2000; Xie et al. 2006; Romatschke and Houze 2010; Rasmussen and Houze 2011; Rasmussen et al. 2014), central Africa, and West Africa (Nicholls and Mohr 2010; Zuluaga and Houze 2015), as well as northeast China (Liu and Liu 2018). These studies have advanced our knowledge and understanding of the frequency and characteristics of intense convection.

The available information is still insufficient to specify the processes that lead to intense thunderstorms over many remote regions of the world. A number of processes may be involved that favor formation of these systems. Detailed analysis of the large-scale fields of temperature, moisture, and wind at standard levels would permit the identification of regions that are preferable for intense thunderstorms. This has inspired the present paper in which we select seven hotspots for high-lightning-flash-rate storms, then investigate the environments that accompany or precede them over the zone covered by TRMM. These include the hotspots of the most intense convection on Earth demonstrated by prior studies (Mohr and Zipser 1996; Liu and Zipser 2005; Zipser et al. 2006; Cecil and Blankenship 2012; Houze et al. 2015; Albrecht et al. 2016; Liu and Liu 2016).

There are different ways to describe the intensity of a convective systems. Lightning is one of the most dramatic aspects of intense thunderstorms, and cloudto-ground lightning flashes have been among the leading causes of weather-related fatalities (Curran et al. 2000). There has been growing public concern in recent years in the forecasting and assessment of the intensity of convective storms around the world based on lightning (e.g., MacGorman and Burgess 1994; Lang and Rutledge 2002; Carey et al. 2003). Previous researchers have developed several empirical relationships between lightning and convective parameters, such as cloud-top height (Price and Rind 1992; Boccippio et al. 2002; Barthe et al. 2010; Dahl et al. 2011; Basarab et al. 2015), upward ice mass flux (Allen and Pickering 2002; Deierling et al. 2008; Finney et al. 2014), convective precipitation rate (Meijer et al. 2001), and updraft characteristics (Wiens 2005; Deierling and Petersen 2008). For example, Deierling and Petersen (2008) found that the total flash rate is highly related to the updraft volume with vertical velocity greater than $5 \mathrm{~m} \mathrm{~s}^{-1}$ as well as greater than $10 \mathrm{~m} \mathrm{~s}^{-1}$. Moreover, flash rate is related to other proxies that are used to define intense convection, as confirmed by using ground- and satellite-based observations (Price and Rind 1992; Carey and Rutledge 1996; Mohr et al. 1996; Petersen et al. 1996; Ushio et al. 2001; Liu et al. 2012). This also implies that intense storms can correspond to various convective variables, which might not necessarily be related to each other. In this study, convective intensity is inferred from the lightning flash rate observed by the TRMM LIS.

The objective in this study is to examine the dynamic and thermodynamic conditions that accompany or precede the most intense thunderstorms, over different regions, and compare their differences and similarities. First, we present the geographical distribution and seasonal variations of high-flash-rate thunderstorms across the tropics and subtropics observed by TRMM. Then the favorable meteorological environments of these events over selected regions are explored, using the European Centre for MediumRange Weather Forecasts interim reanalysis (ERAInterim; Dee et al. 2011). Finally, a discussion of the similarities and differences in the favorable environments associated with these events is provided. With this objective, this paper is arranged in the following 
TABLE 1. Mean of selected intensity proxies for intense CFs (more than 50 lightning flashes) and weak CFs (with 1-3 lightning flashes) over seven selected regions. The values in the parentheses are for weak CFs. The last two columns represent the 25 th and 75 th percentiles of convective precipitation area.

\begin{tabular}{|c|c|c|c|c|c|c|c|}
\hline \multirow{2}{*}{ Tropics } & \multirow{2}{*}{$\begin{array}{c}\text { Regions } \\
\text { COLOM (JJA) }\end{array}$} & \multirow{2}{*}{$\frac{\text { MAXHT40 }(\mathrm{km})}{11.7(3.2)}$} & \multirow{2}{*}{$\frac{\text { MIN85PCT }(\mathrm{K})}{87(242)}$} & \multirow{2}{*}{$\frac{\text { MIN37PCT }(\mathrm{K})}{199(275)}$} & \multicolumn{3}{|c|}{ Convective precipitation area $\left(\mathrm{km}^{2}\right)$} \\
\hline & & & & & $2766(211)$ & $1394(102)$ & $3408(244)$ \\
\hline & SAHEL (JJA) & $10.8(3.7)$ & $103(238)$ & $209(278)$ & $3211(238)$ & $1893(102)$ & $4120(265)$ \\
\hline & CONGO (MAM) & $10.9(3.9)$ & $97(249)$ & $206(275)$ & $3866(206)$ & $1480(102)$ & $4594(244)$ \\
\hline & NWM (JJA) & $12.5(4.2)$ & $101(241)$ & $200(275)$ & $2680(203)$ & $1628(102)$ & $3459(224)$ \\
\hline \multirow[t]{3}{*}{ Subtropics } & HIMA (MAM) & $9.7(3.5)$ & $155(255)$ & $226(277)$ & $2288(190)$ & $1089(102)$ & $3093(204)$ \\
\hline & SCUS (AMJ) & $11.8(3.2)$ & $99(251)$ & $188(279)$ & $5270(209)$ & $1780(102)$ & $5805(244)$ \\
\hline & ARGEN (DJF) & $11.5(2.5)$ & $114(243)$ & $195(279)$ & $4635(236)$ & $2319(102)$ & $6023(265)$ \\
\hline
\end{tabular}

order: data and methodology in section 2, results in section 3 , followed by summary and discussion in section 4 .

\section{Data and methods}

\section{a. TRMM convective feature datasets for identifying intense thunderstorms}

TRMM carried multiple instruments (Kummerow et al. 1998), including the Precipitation Radar (PR), TRMM Microwave Imager (TMI), Visible and Infrared Scanner (VIRS), and LIS. LIS has provided valuable observations in studying lightning (Cecil et al. 2005; Petersen et al. 2005; Pessi and Businger 2009; Xu et al. 2010). With $\sim 70 \%-90 \%$ detection efficiency (Boccippio et al. 2002) and $\sim 90$-s sampling duration, the total lightning rate, composed of both cloud-to-ground and intracloud lightning, can be derived for each thunderstorm that TRMM samples.

In this study, 16-yr (1998-2013) TRMM, version 7, products from PR and LIS are used. First, convective features (CFs) are defined by grouping the contiguous area with convective precipitation derived with PR after Liu and Zipser (2013), using the precipitation feature approach described in Liu et al. (2008). The LIS lightning flash counts are summarized within each $\mathrm{CF}$ as an indicator of the convective intensity. Then four categories of storms are classified using the flash counts with 90-s sampling duration: no flash, weak (1-3 flashes), moderate (3-50 flashes), and the most intense $(>50$ flashes). This classification is arbitrary. Note that the $\mathrm{CF}$ as defined here can range from a single cell storm to a large, organized convective complex. The highest flash rates generally result from $\mathrm{CFs}$ with a precipitating area greater than $1000 \mathrm{~km}^{2}$ (Table 1 ). Over the 16 -yr period, a total of $\sim 25$ million CFs was observed by TRMM. This study only includes CFs with at least four contiguous pixels (with size greater than $\sim 75 \mathrm{~km}^{2}$ ). There are more samples in the subtropical latitudes due to the $\pm 35^{\circ}$ orbit (Fig. 1a).
To demonstrate how representative 50 or more lightning flashes per $\mathrm{CF}$ is of intense convection, maximum 40-dBZ echo-top height and minimum brightness temperature at $85-$ and $37-\mathrm{GHz}$ channels are listed for CFs with more than 50 flashes in Table 1. The mean convective precipitation area of intense CFs with more than 50 flashes over those selected regions are greater than $2000 \mathrm{~km}^{2}$. This indicates that these high-flash-rate thunderstorms generally originate from organized convection with large convective precipitation area. The mean maximum $40-\mathrm{dB} Z$ echo-top
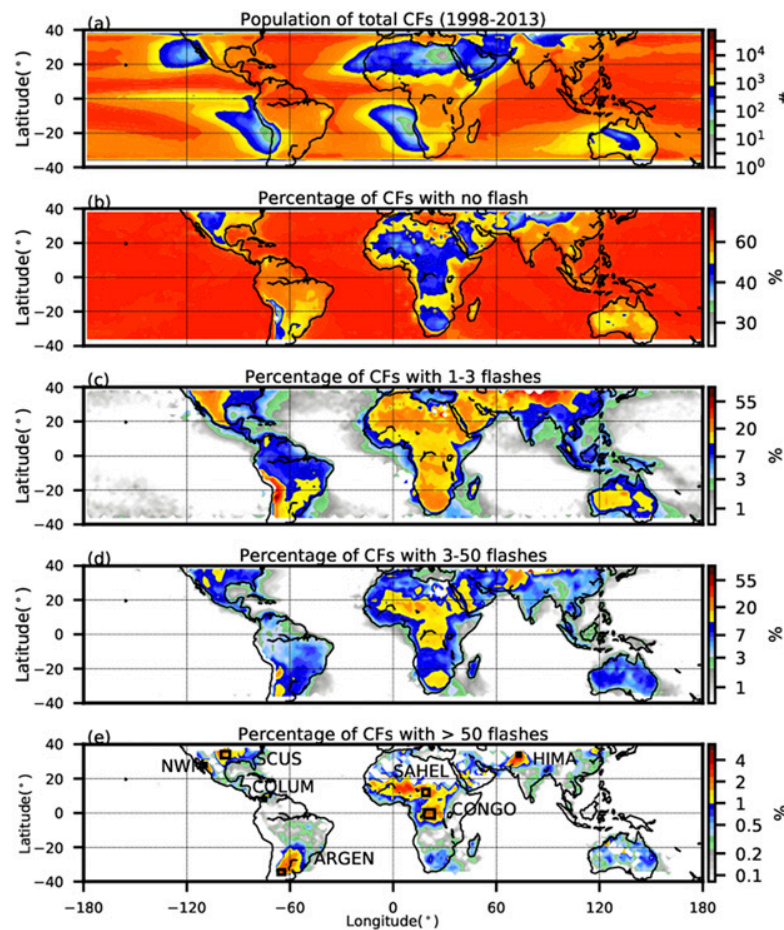

FIG. 1. Geographical distribution of the population of total CFs and percentage of CFs with different flashes: (a) total CFs, (b) with no flash, (c) with 1-3 flashes, (d) with 3-50 flashes, and (e) with $>50$ flashes. The distribution is created on a $2^{\circ} \times 2^{\circ}$ grid from 16 years (1998-2013) of TRMM observations. 

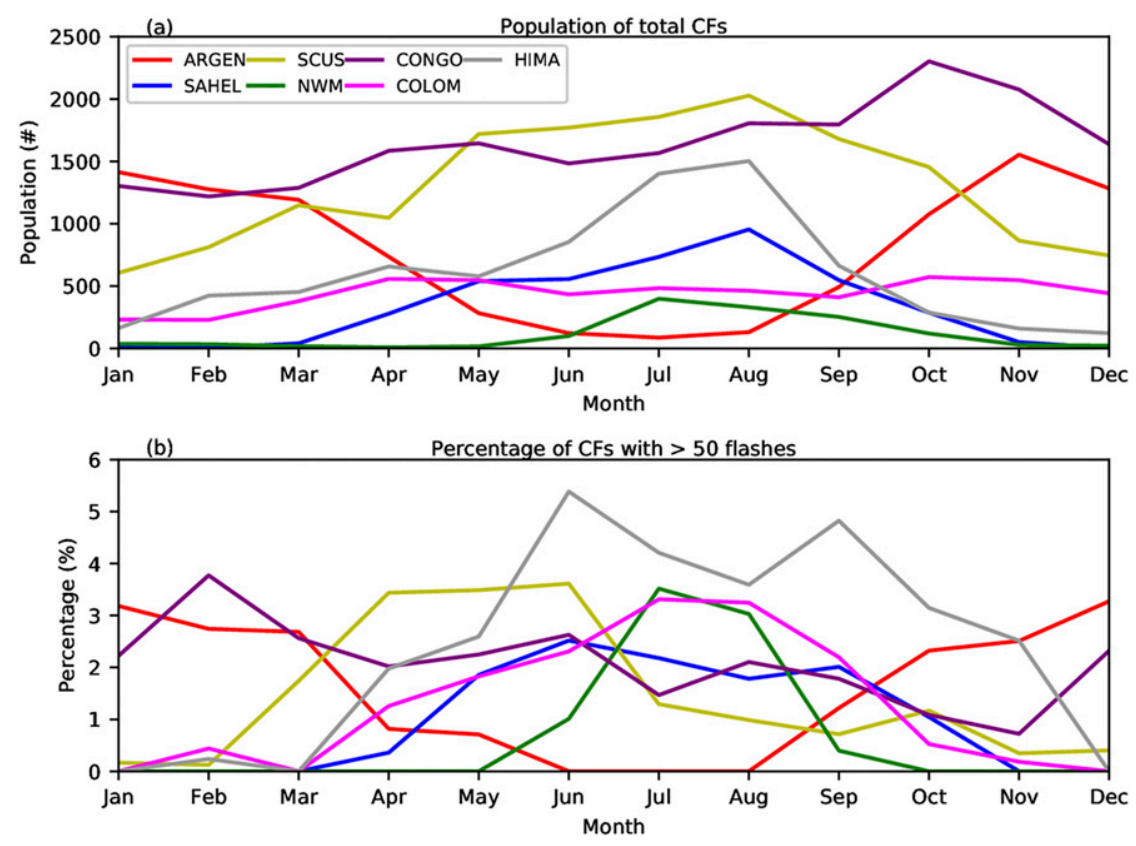

FIG. 2. Seasonal variation of CFs and intense CFs with $>50$ flashes. (a) Population of total CFs

(b) Percentage of intense CFs with $>50$ flashes.

heights (MAXHT40) of high-flash-rate CFs are generally greater than $10 \mathrm{~km}$, corresponding to the top $0.1 \%$ most intense precipitation systems (Zipser et al. 2006), and deep convective cores (Houze et al. 2015). Wu et al. (2016) also showed that the 1000 most intense convective systems over the southern Himalayas front, with 40-dBZ echo-top heights greater than $10 \mathrm{~km}$, correspond to those systems having the highest flash rate ( $\geq 32$ flashes per minute). According to Zipser et al. (2006), the minimum brightness temperature at $85 \mathrm{GHz}$ (MIN85PCT) colder than $160 \mathrm{~K}$ is consistent with the top $1 \%$ most intense systems while the minimum brightness temperature at $37 \mathrm{GHz}$ (MIN37PCT) colder than $220 \mathrm{~K}$ corresponds to the top $0.1 \%$ most intense systems. Therefore, though only a high lightning flash rate is used, the low microwave brightness temperatures and the high $40-\mathrm{dBZ}$ echo tops confirm that $\mathrm{CFs}$ with more than 50 flashes are generally the most extreme convective storms, hereafter using this as a synonym for "intense thunderstorms," as in Zipser et al. (2006).

\section{b. Selected regions for the highest-flash-rate thunderstorms}

Regions with frequent intense convection, identified by space radar, passive microwave, and lightning sensors, have been demonstrated for more than a few decades (e.g., Spencer and Santek 1985; Zipser et al. 2006; Said et al. 2013; Cecil et al. 2015; Albrecht et al. 2016). However, it is still fruitful to reexamine the climatological frequency of high-flash-rate thunderstorms on the basis of 16-yr TRMM-LIS comprehensive datasets. The percentage of the storms in different categories are identified by the $\mathrm{CFs}$ with no flashes, $1-3,3-50$, and $>50$ flashes divided by the total number of $\mathrm{CFs}$ in each $2^{\circ} \times 2^{\circ}$ box shown in Fig. 1. The ocean has a much higher percentage of CFs with no flashes than land. Central Africa, mountains, and a few desert regions have much lower fraction of CFs with no flashes. The geographical distribution of percentage of weak, moderate and intense thunderstorms are consistent with prior studies (e.g., Orville and Henderson 1986; Zipser and Lutz 1994; Christian et al. 2003; Liu et al. 2012). Thunderstorms are found far more often over land than over the ocean. Over land, the most intense thunderstorms with more than 50 flashes, corresponding to about 33 flashes per minute, tend to occur in a few hotspot regions (Fig. 1e). This inspires the examination of the nature of the most intense thunderstorms over these hotspots. In this study, we choose regions (boxes as shown in Fig. 1e) having CFs with the highest flash rates. These regions include the south-central United States (SCUS; $32^{\circ}$ $36^{\circ} \mathrm{N}, 95^{\circ}-100^{\circ} \mathrm{W}$ ), northwest Mexico (NWM; $27^{\circ}$ $29^{\circ} \mathrm{N}, 108^{\circ}-110^{\circ} \mathrm{W}$ ), Argentina (ARGEN; $33^{\circ}-36^{\circ} \mathrm{S}$, $63^{\circ}-67^{\circ} \mathrm{W}$ ), the Sahel (SAHEL; $\left.10^{\circ}-14^{\circ} \mathrm{N}, 17^{\circ}-21^{\circ} \mathrm{E}\right)$, Congo (CONGO; $3^{\circ} \mathrm{S}-2^{\circ} \mathrm{N}, 18^{\circ}-24^{\circ} \mathrm{E}$ ), Colombia 
TABLE 2. Mean thermodynamic and dynamic parameters of intense and weak CFs during the warm season over selected regions. The values in the parentheses are for intense CFs. The low-level shear (SHEAR $\left.{ }_{1-6 \mathrm{~km}}\right)$ is calculated between 1 and $6 \mathrm{~km}$; the storm-relative helicity $\left(\mathrm{SRH}_{1-3 \mathrm{~km}}\right)$ is calculated between 1 and $3 \mathrm{~km}$ assuming static storm motion. SHL donates the near-surface specific humidity. RHM represents the averaged midlevel $(700-500 \mathrm{hPa})$ relative humidity $(\mathrm{RH})$.

\begin{tabular}{|c|c|c|c|c|c|c|c|c|c|}
\hline & Regions & No. & $\begin{array}{c}\text { CAPE } \\
\left(\mathrm{J} \mathrm{kg}^{-1}\right)\end{array}$ & $\begin{array}{c}\mathrm{CIN} \\
\left(\mathrm{J} \mathrm{kg}^{-1}\right)\end{array}$ & $\begin{array}{l}\text { SHEAR }_{1-6 \mathrm{~km}} \\
\quad\left(\mathrm{~m} \mathrm{~s}^{-1}\right)\end{array}$ & $\begin{array}{c}\text { SHL } \\
\left(\mathrm{g} \mathrm{kg}^{-1}\right)\end{array}$ & RHM (\%) & $\operatorname{LCL}(\mathrm{km})$ & $\begin{array}{c}\mathrm{SRH}_{1-3 \mathrm{~km}} \\
\left(\mathrm{~m}^{2} \mathrm{~s}^{-2}\right)\end{array}$ \\
\hline \multirow[t]{4}{*}{ Tropics } & COLOM (JJA) & $113(41)$ & $1897(2611)$ & $22(13)$ & $7.8(8.4)$ & $16.7(17.6)$ & $67.2(68.1)$ & $1.21(0.98)$ & $8.8(20.8)$ \\
\hline & SAHEL (JJA) & $364(51)$ & 1477 (1738) & $38(32)$ & $10.6(11.7)$ & $17.4(17.3)$ & $67.5(65.2)$ & $1.20(1.22)$ & $26.3(36.1)$ \\
\hline & CONGO (MAM) & $828(105)$ & 1677 (2046) & $25(20)$ & $5.9(6.9)$ & $18.1(18.5)$ & $65.9(59.6)$ & $0.71(0.69)$ & $6.0(7.9)$ \\
\hline & NWM (JJA) & $169(25)$ & 1161 (1581) & $46(44)$ & $5.1(7.0)$ & $14.6(14.4)$ & $69.8(71.4)$ & $2.37(2.55)$ & $5.3(10.9)$ \\
\hline \multirow[t]{3}{*}{ Subtropics } & HIMA (MAM) & $206(28)$ & $792(1270)$ & $63(66)$ & $11.8(12.9)$ & $10.0(11.8)$ & $67.1(61.8)$ & $2.42(2.45)$ & $32.1(35.7)$ \\
\hline & SCUS (AMJ) & 701 (164) & 494 (1156) & $38(58)$ & $13.2(14.6)$ & $11.4(14.2)$ & $57.9(51.4)$ & $1.08(1.43)$ & $50.0(80.5)$ \\
\hline & ARGEN (DJF) & 706 (124) & 748 (1349) & $54(41)$ & $15.6(16.8)$ & $12.3(13.7)$ & $61.3(61.0)$ & $1.26(1.21)$ & $31.2(55.7)$ \\
\hline
\end{tabular}

(COLOM; $\left.7^{\circ}-9^{\circ} \mathrm{N}, 74^{\circ}-76^{\circ} \mathrm{W}\right)$, and the Himalayas (HIMA; $33^{\circ}-35^{\circ} \mathrm{N}, 72^{\circ}-74^{\circ} \mathrm{E}$ ).

The seasonal variations of total CFs and intense CFs with more than 50 flashes are shown in Fig. 2. It is not surprising that intense thunderstorms are found more frequently in the warm season. There is a smaller seasonal variation of both the total number and the percentage of intense CFs over CONGO than other regions. Two peaks of intense thunderstorms are found over HIMA in June and September, which is consistent with prior studies (Qie et al 2014). It is well known that thunderstorms are typical spring and summer phenomena (e.g., Johns 1982; Uyeda et al. 2001; Qie et al. 2003; Schulz et al. 2005; Taszarek et al. 2015) due to more intense low-level atmosphere heating and higher equivalent potential temperature (Miller and Fritsch 1991). Therefore, the environments of intense CFs in the most active months are discussed for each region, respectively.

\section{c. ERA-Interim data for large-scale conditions}

To derive large-scale thermodynamic and kinematic environments for intense thunderstorms, the ERA-Interim data (Dee et al. 2011) are used. With 37 vertical levels and $0.75^{\circ} \times 0.75^{\circ}$ horizontal resolution, the ERA-Interim dataset is available every $6 \mathrm{~h}$. In addition to the base state variables, for example, temperature, geopotential height, relative humidity, and horizontal wind components, additional parameters, that is, convective available potential energy (CAPE), convective inhibition (CIN), and the lifting condensation level (LCL), are derived from these basic variables. For each $\mathrm{CF}$, those basic variables and additional parameters at the closet point to the centroid of the $\mathrm{CF}$ are derived. To focus on the preconvective conditions, the 6-hourly variables prior to the CF time are used. In this study, we use the most unstable CAPE (hereinafter referred to as CAPE), which is calculated by lifting parcels from multiple pressure levels between the surface and $700 \mathrm{hPa}$ and finding the highest value. We do not account for the latent heating due to freezing. The low-level wind shear and storm relative helicity between 1-3 and 1-6 km for each CF are also calculated. For CFs selected over complex terrain, the wind vector at $1 \mathrm{~km}$ is used to derive the shear and helicity to avoid potential contamination of topography to the near-surface wind values on $0.75^{\circ}$ grids. TRMM only provides snapshots of CFs, so we do not attempt to estimate storm motion in calculating helicity values. Because similar conclusions can be drawn from 1-3- and 1-6-km shear and helicity, only the results of $1-6-\mathrm{km}$ shear and $1-3-\mathrm{km}$ helicity are presented here.

For each $\mathrm{CF}$, a $30^{\circ} \times 30^{\circ}$ grid of the large-scale conditions centered at the $\mathrm{CF}$ is obtained from the closest ERA-Interim product prior to the CF time. We composite the large-scale fields relative to the thunderstorm centers. The horizontal or vertical traditional and derived parameters centered at CFs are averaged to examine the common large-scale features of thunderstorms. The differences between intense and weak thunderstorms are examined by calculating anomalies of each large-scale field, comparing the composite fields of the intense CFs with more than 50 flashes to weak CFs with 1-3 flashes. Because sometimes weak and intense CFs may coexist in the same satellite overpasses, the orbits with intense CFs are removed from samples to calculate the large-scale condition background for weak CFs. After this, it is still possible that some weak CFs occur close to an intense CF that is just outside of a TRMM overpass. Therefore, some of the weak CFs may not be under pure "weak thunderstorm" environments. However, because there are many more weak thunderstorms than intense ones (Table 2), the composite of weak 
Composite of ERA-Interim for CFs with $>50$ flashes in SCUS (AMJ)
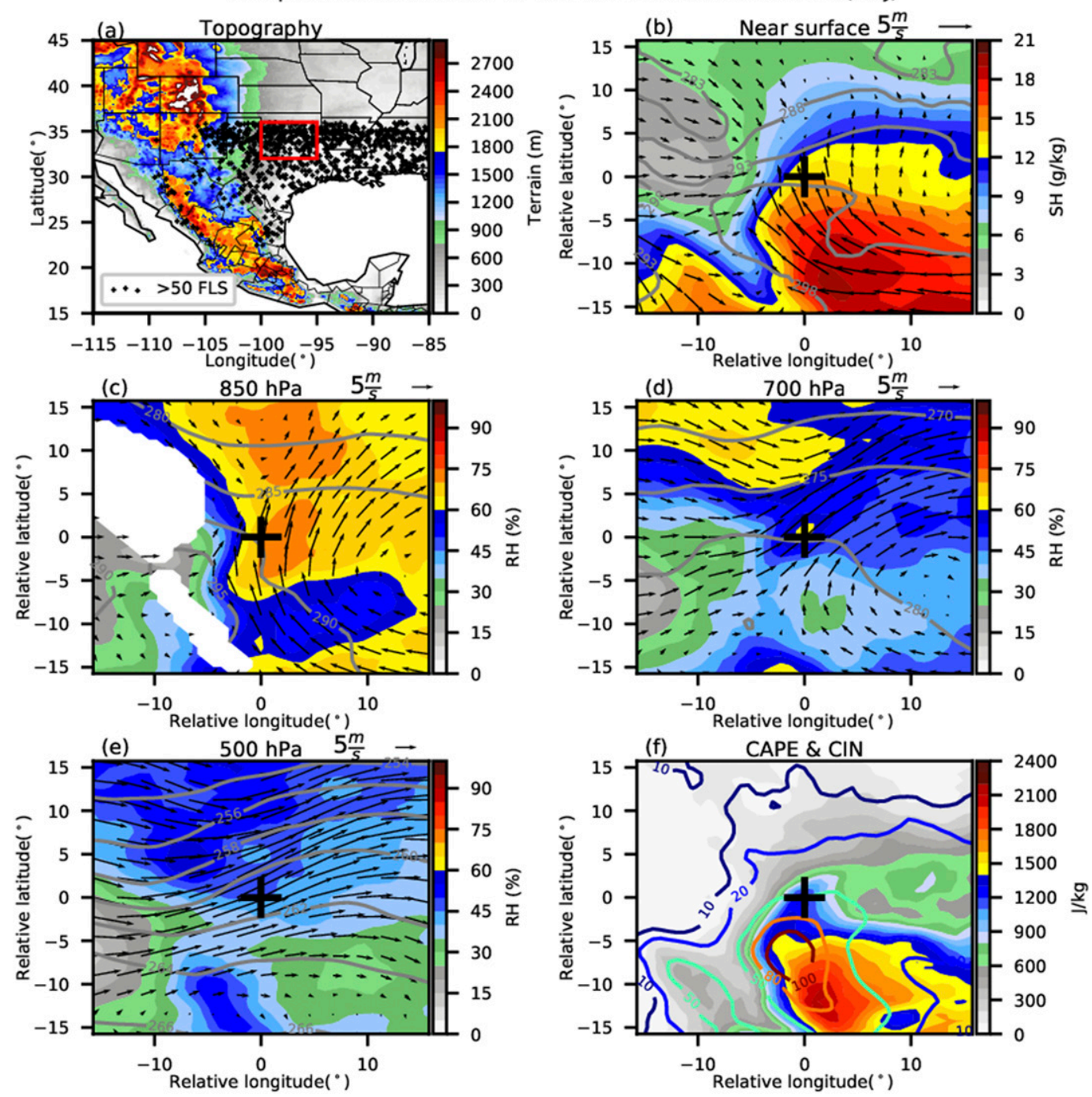

FIG. 3. Environmental composites for intense CFs with $>50$ flashes during AMJ over SCUS. (a) Locations of intense CFs (black crosses) and topography (color fill). The red box represents the region of interest. (b) Composite 10-m wind vectors, 2-m temperature (contours), and 2-m specific humidity (color fill). (c)-(e) Composite wind vectors, temperature (contours), and relative humidity (color fill) at (c) 850, (d) 700, and (e) $500 \mathrm{hPa}$. (f) Composite CAPE (color fill) and CIN (contours). The bold black cross in (b)-(f) marks the centroid location of the intense CFs with $>50$ flashes. Composites are made using ERA-Interim data starting at the surface pressure. The area with high terrain is left blank if the terrain reaches that level in all analyses.

CFs should be dominated by weak thunderstorm conditions.

\section{Results}

The occurrence of intense convection in the United States has been highly correlated with the synoptic condition (e.g., Barnes and Newton 1986; van Delden 2001; Doswell 2001; Tuttle and Carbone 2004; Schumacher and Johnson 2005; Trier et al. 2006). Therefore, we select a similar methodology to explore the environments conducive to intense thunderstorms. This similar methodology then is applied to other regions to determine their preferred synoptic conditions for intense convection. Then the similarities and differences in the dynamic and thermodynamic factors for intense thunderstorms are compared among different regions.

\section{a. SCUS (North Texas and Oklahoma; AMJ)}

Thunderstorms over the southern plains of the United States have been well studied for more than half a 

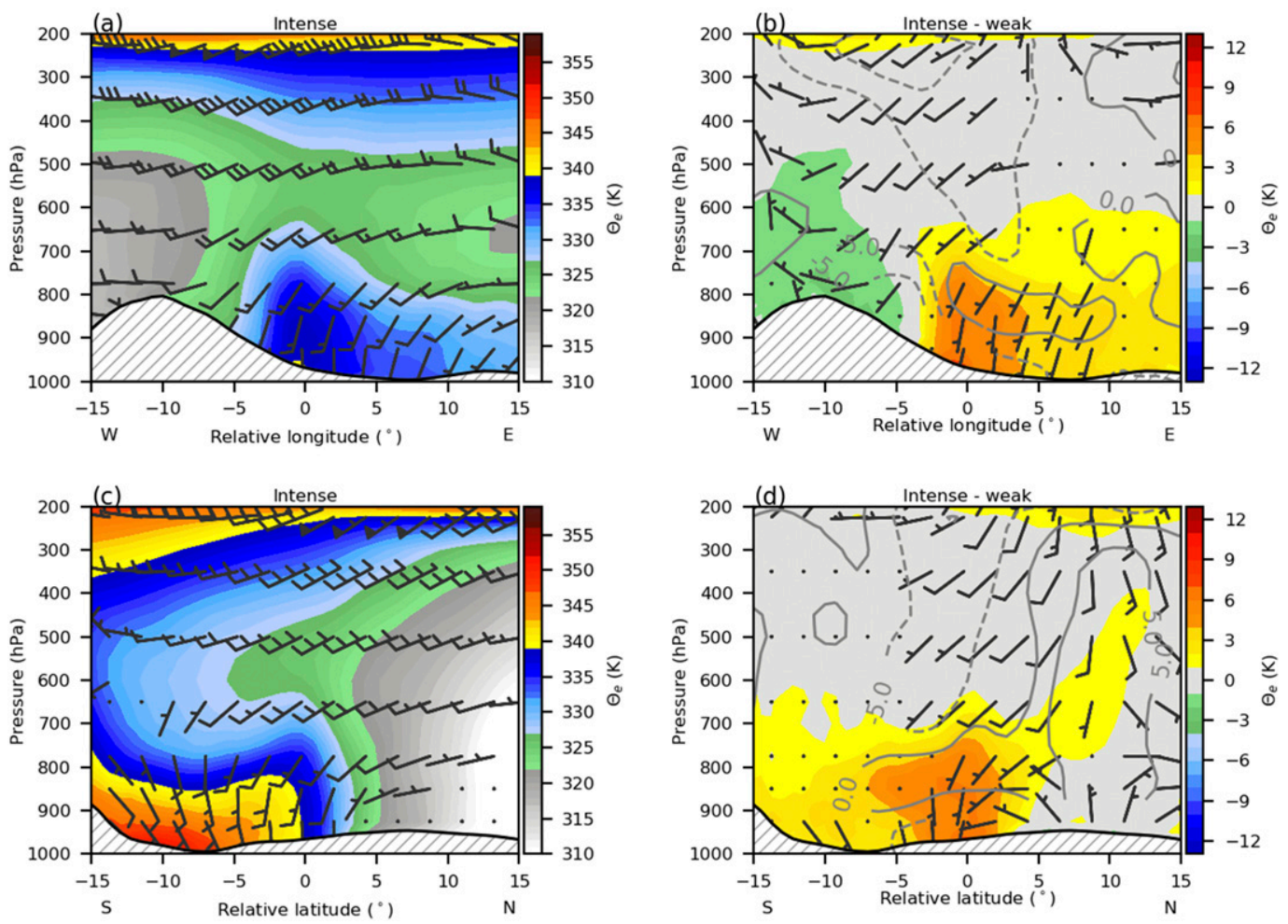

FIG. 4. (a) Composite vertical cross section of wind and equivalent potential temperature (color fill) of intense CFs with $>50$ flashes along the latitude where CFs occur during AMJ over SCUS. (b) Difference cross section of wind, equivalent potential temperature, and $\mathrm{RH}$. The difference is the condition of weak CFs subtracted from the condition of intense CFs. The color fill represents equivalent potential temperature and the contours lines show the difference in RH. Positive values are in solid contours and negative values are in dashed contours. (c) As in (a), but along the longitude that CFs occur. (d) As in (b), but along the latitude that CFs occur. The thick black lines present the mean near-surface pressure.

century. As early as the 1950s (Beebe 1958; Fujita 1958), boundaries between moist air originating over the Gulf of Mexico and dry air originating over arid regions in northern Mexico, eastern New Mexico, and western Texas, or so-called drylines (e.g., Rhea 1966; Schaefer 1974; Thompson and Edwards 2000), have been identified as a major focus of intense thunderstorms over SCUS. More than $40 \%$ of thunderstorms in April-June (AMJ) have been found to be associated with the drylines (e.g., Rhea 1966; Schaefer 1974; Peterson 1983). Much effort has been made to explore the drylines and their association with convection initiation in the United States (e.g., Benjamin and Carlson 1986; Bluestein et al. 1988; Ziegler and Hane 1993; Shaw et al. 1997; Atkins et al. 1998; Ziegler and Rasmussen 1998; Hoch and Markowski 2005).

Benjamin and Carlson (1986) suggest that a favorable environment for the formation of intense thunderstorms is frequently a product of both surfacerelated processes and large-scale flow patterns. Surface processes are often related to the terrain configuration (McCarthy and Koch 1982; Carlson and Ludlam 1968; Steenburgh and Mass 1994). Therefore, the locations of intense CFs, as well as the topography, are shown (Fig. 3a) before investigating their large-scale field environments. Then Figs. $3 b-f$ present the composite ERA-Interim dynamic and thermodynamic conditions centered at the location of each intense $\mathrm{CF}$ in AMJ over SCUS.

The centroid of the intense thunderstorms is located along the moist side of the large-gradient of specific humidity (SH) $2 \mathrm{~m}$ above the surface, which indicates the position of the dryline in Fig. 3b. Southeasterly flow brings moist air $\left(\mathrm{SH}>12 \mathrm{~g} \mathrm{~kg}^{-1}\right)$ from the Gulf of Mexico toward the storm center. The convergence between the warmmoist flow and the westerly dry flow behind the dryline is identifiable. The convergence at the near surface creates ascent (Hane et al. 1997; Richter and Bosart 2002; Murphey et al. 2006). Ziegler et al. (1997) confirmed that updrafts of up to 
Composite of ERA-Interim for CFs with > 50 flashes in HIMA (MAM)
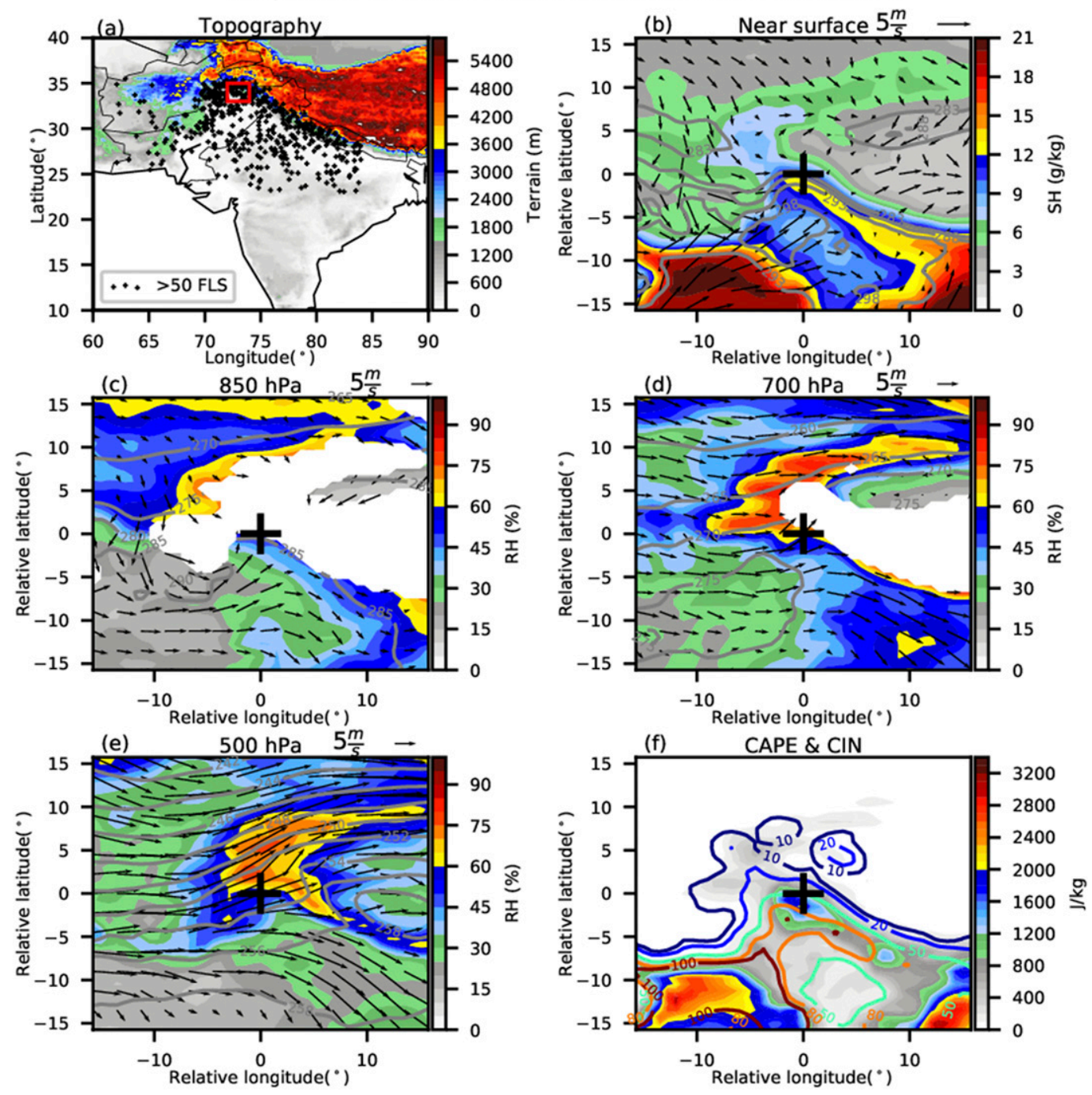

FIG. 5. As in Fig. 3, but for HIMA during MAM.

$5 \mathrm{~m} \mathrm{~s}^{-1}$ are common along dryline convergence bands. The continued strong southerly wind $\left(>10 \mathrm{~m} \mathrm{~s}^{-1}\right)$ at $850 \mathrm{hPa}$ indicates the low-level jet (Fig. 3c). At $700 \mathrm{hPa}$, south of the storm centroid, hot and dry continental air flows northeastward above moist lowlevel air providing large CIN (Carlson and Ludlam 1968). Farther aloft, the shortwave trough, ahead of a thermal trough, is identifiable based on the curvature in the wind field on the 500-hPa composite map (Fig. 3e). In accordance with past studies (e.g., Rhea 1966; Hane et al. 1997; Ziegler et al. 1997; Weiss et al. 2006), a $500-\mathrm{hPa}$ trough is a frequent feature together with a dryline. Schultz et al. (2007) also noted that strong synoptic patterns contribute to the strength of the dryline. In the composite CAPE map, the storm centroid is within the modest CAPE values $\left(\sim 1200 \mathrm{~J} \mathrm{~kg}^{-1}\right)$, with larger values farther south. Although there is an extensive area of large CAPE $\left(>1500 \mathrm{~J} \mathrm{~kg}^{-1}\right)$ to the south, intense storms occur at the northern edge of the large CAPE region, where CIN values are lower. It implies that CIN can both hinder and help the formation of intense thunderstorms. A large CIN can suppress convection even when CAPE favors intense convection to the south. At the same time, a moderate CIN also can help accumulate the energy allowing intense convection to form even when CAPE is relatively weaker. Note that the impact of intense thunderstorms on their environment is not considered.

Composite cross sections of equivalent potential temperature $\Theta_{e}$ related to the intense thunderstorms, as well as the differences in equivalent potential 
HIMA (MAM)
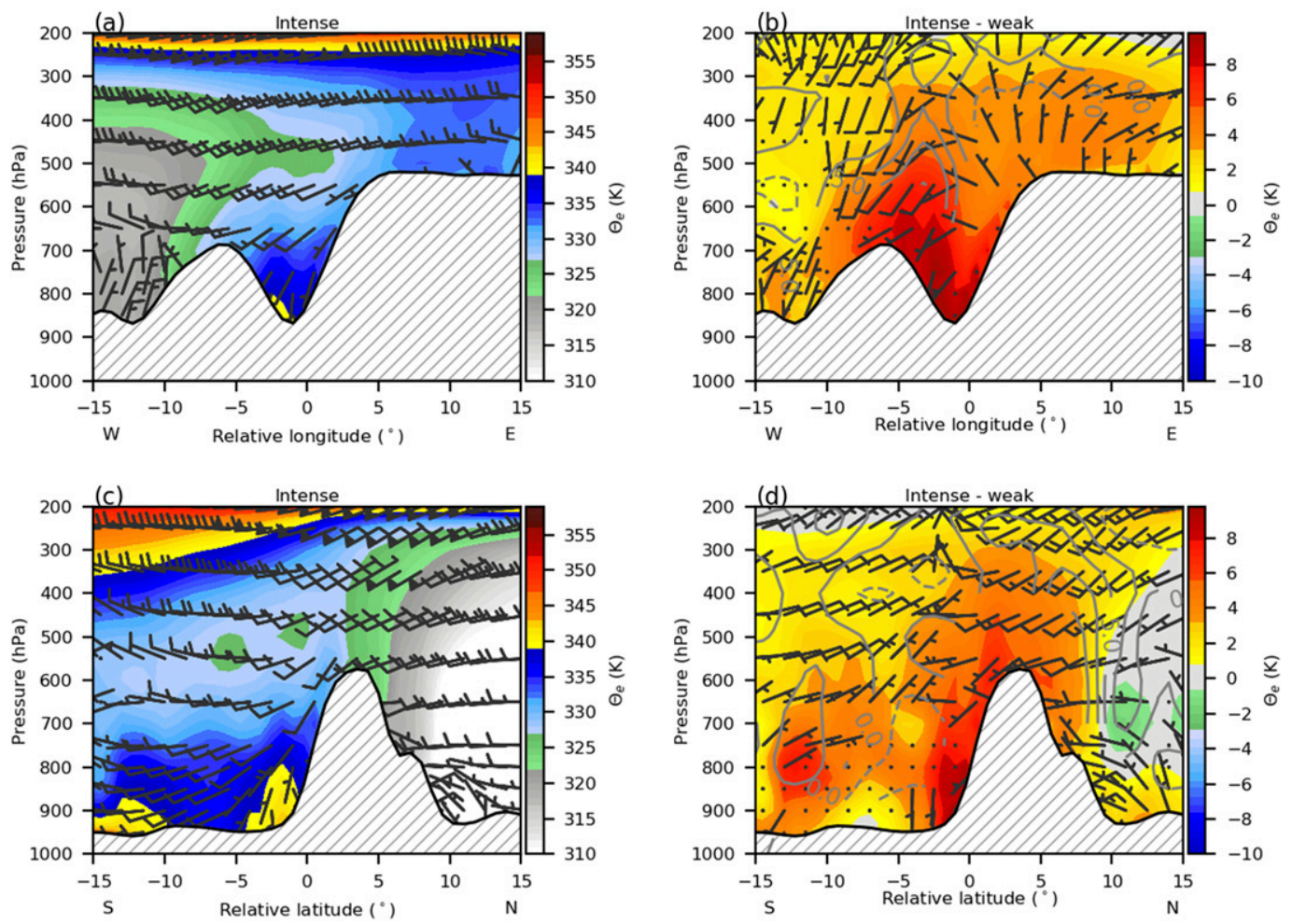

FIG. 6. As in Fig. 4, but for HIMA during MAM.

temperature and $\mathrm{RH}$ compared to the weak ones, are constructed at the storm-centroid latitude-longitude to provide further insight into the favorable properties of intense thunderstorm environments (Fig. 4). Characterized by a sharp gradient in $\Theta_{e}$, the dryline profile is similar to the dryline structure suggested by prior studies (Rockwood and Maddox 1988). The high $\Theta_{e}$ from the surface to around $700 \mathrm{hPa}$ indicates a deep southerly warm moist flow (Figs. 4a,c). Low-level warm moist advection, together with the southwesterly dry flow aloft (low $\Theta_{e}<330 \mathrm{~K}$ ), create a potentially unstable environment. The southerly wind at low levels (below $700 \mathrm{hPa}$ ) and the strong westerly flow above creates a strong wind shear from 1 to $6 \mathrm{~km}$ (about $14 \mathrm{~m} \mathrm{~s}^{-1}$ ). Increased strength of the southerly wind for intense thunderstorms implies a stronger warm moist advection for intense thunderstorms than for weak ones (Figs. 4b,d). Near the storm centroid, the positive difference in RH implies a moisture plume around $800 \mathrm{hPa}$. Compared to weak thunderstorms, intense thunderstorms are associated with warm moist advection at low levels and a drier airflow above $700 \mathrm{hPa}$ (Figs. 4b,d). This indicates that the composite environment of intense thunderstorms has more instability than the composite environment of weak CFs.
The reexamination of the large-scale conditions of intense thunderstorms over the SCUS confirms previous studies about how large-scale patterns and the physical processes interact and create a favorable environment for the development of such events. This agreement with prior studies adds confidence for the approaches and data used here. Next, we apply similar analysis to other regions.

\section{b. Southwest slope of HIMA (northern Pakistan)}

Convection just southwest of the Himalayas, with high lightning rates (e.g., Christian et al. 2003; Zipser et al. 2006; Cecil et al. 2015) has been a frequent scientific topic for researchers. Asian monsoons play a critical role in the occurrence of intense convection over this region (Romatschke et al. 2010; Qie et al. 2014; Virts and Houze 2016). Most of the TRMMLIS-identified intense CFs over the region are found in the warm season (May-September), as shown in Fig. 2a. More intense CFs are observed in summer than in spring. A higher percentage of the intense CFs is found in June (Fig. 2b). Previous studies have also revealed that convective systems in the premonsoon period(March-May) over this region are more intense than in other seasons, with a maximum in lightning 

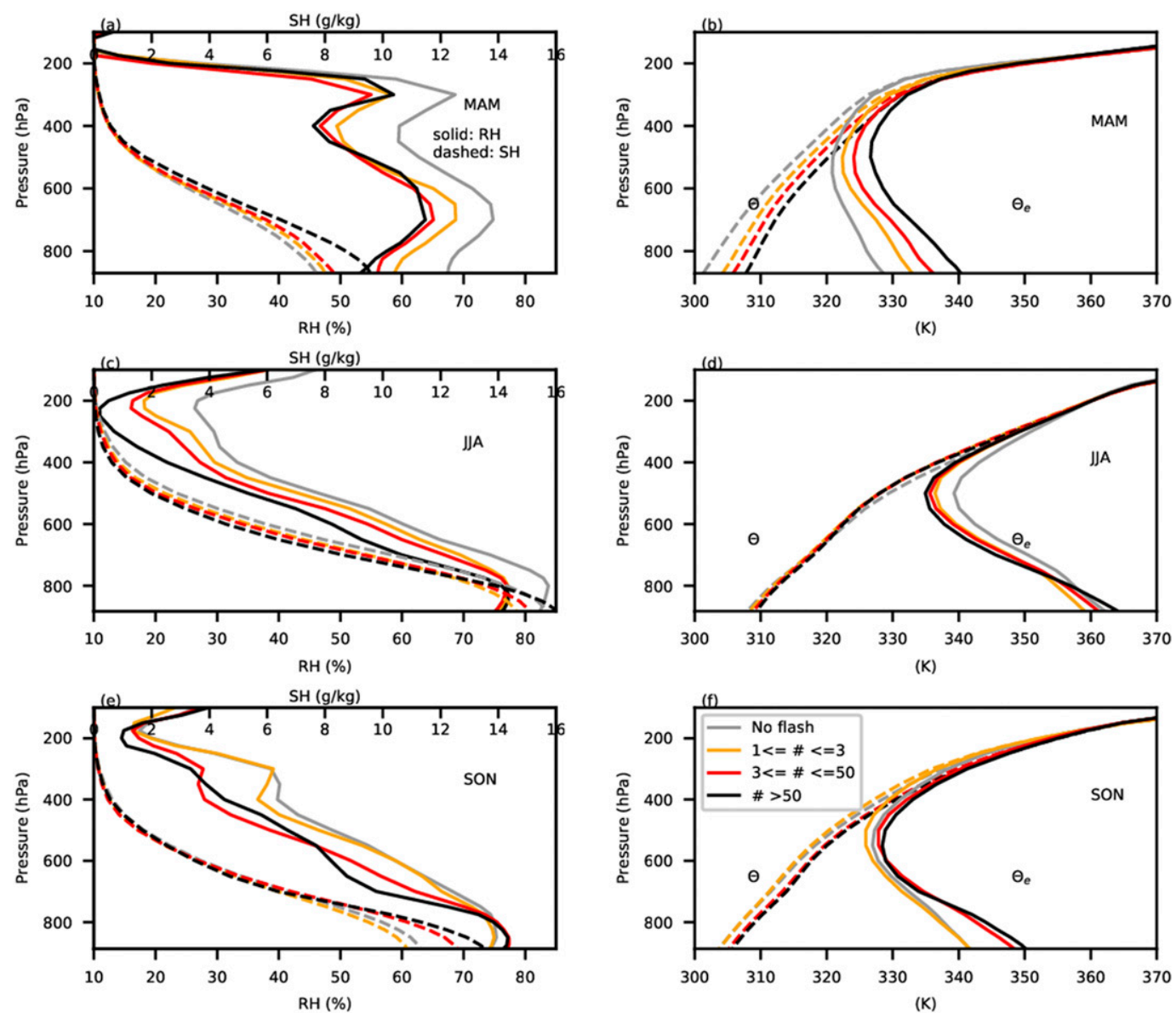

FIG. 7. Composite profiles of (left) $\mathrm{RH}$ and $\mathrm{SH}$ and (right) potential and equivalent potential temperatures for CFs with different flashes in different seasons over HIMA. (a) RH (solid) and SH (dashed) in spring (MAM). (b) Potential and equivalent potential temperatures in MAM. (c) RH in JJA. (d) Potential and equivalent potential temperatures in JJA. (e) RH in SON. (f) Potential and equivalent potential temperatures in SON.

activity (Lal and Pawar 2009; Ranalkar and Chaudhari 2009). We have therefore examined the favorable environments of intense thunderstorms in three seasons: spring [March-May (MAM)], summer (JJA), and fall [September-November (SON)]. Here, we only show the spring synoptic pattern of intense thunderstorms but include composite vertical profiles from three seasons for the comparison among different seasons.

The composites of large-scale conditions of intense storms, as well as the topography and locations of intense thunderstorms, are shown in Fig. 5. The storm centroid was found in a region with a strong nearsurface humidity gradient along the Himalayan foothills (also at other levels, Fig. 5b). Weston (1972) and Wu et al. (2013) also suggested that severe convection tends to occur in regions with a sharp moisture gradient at the low layer. Another key feature found at the near surface is the two moisture pathways, which have been suggested by Wu et al. (2016). One is from the Bay of Bengal, along the base of the Himalayas, even though the averaged wind vectors do not favor this source. Another one is from the Arabian Sea (SW), which is consistent with the moisture advection in Fig. 6b. We speculate that winds from the Bay of Bengal occur less frequently than the ones from the SW and therefore do not obviously appear in the composite field. Southwesterly flow at low levels encounters the dry north-northwesterly air flowing from the Afghan highlands at midtroposphere over the region. The southwesterly low-level jet brings warm, moist air from the Arabian sea into the storm centroid area, which increases the convective instability. South of the storm centroid, the westerly flow from the Afghan highland is dry from 700 to $500 \mathrm{hPa}$. At $500 \mathrm{hPa}$, the storm centroid is ahead of a shortwave 

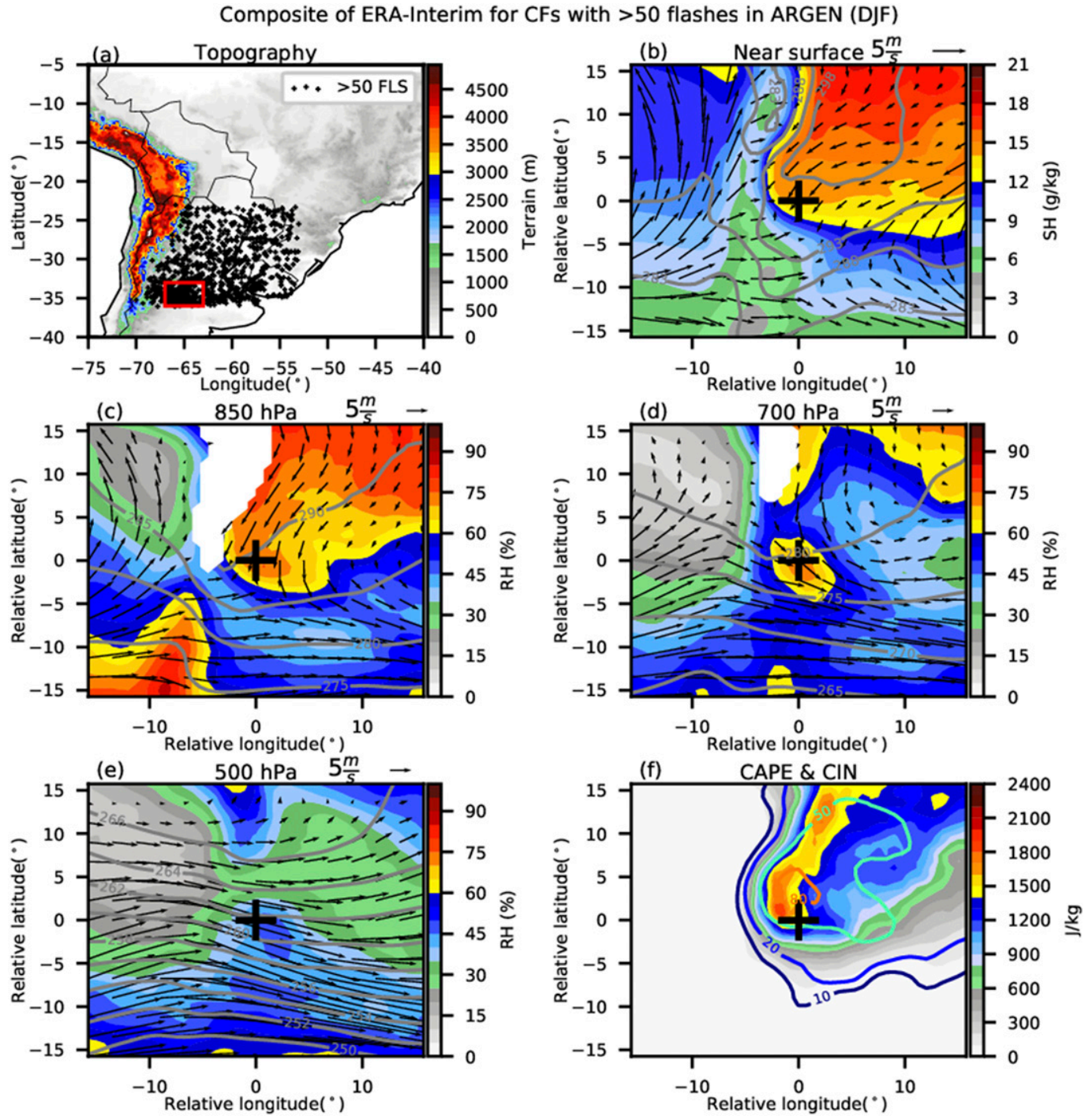

FIG. 8. As in Fig. 3, but for ARGEN during DJF.

trough (Fig. 5e). The large-scale ascent ahead of the trough may play a role in triggering convection over HIMA, while other vertical lifting mechanisms (e.g., orography, surface heating) may be equally important over the area (Carlson et al. 1983; Houze et al. 2007; Romatschke et al. 2010). Representative of the boundary layer moisture and temperature stratification, CAPE values are consistent with the nearsurface moisture distribution, as shown in Fig. 5b. The storm centroid located within the modest CIN also suggests that thunderstorms tend to form along the lid edge, created by the hot, dry air above the lowlevel moist air. In spite of a large CAPE, large CIN $\left(>100 \mathrm{~J} \mathrm{~kg}^{-1}\right)$ southwest of the storm centroid likely suppresses the development of convection as shown in Fig. 5a. It indicates that even when the right conditions are met at the surface to the southwest of the storm centroid, the capping inversion can prevent the release of convective instability until the CIN is relatively small at the foothills of the northwestern Himalayas (Medina et al. 2010). Figures 6a and $6 \mathrm{c}$ demonstrate the vertical wind shear over the intense thunderstorm region. Note that intense thunderstorms have lower relative humidity at low levels than weaker thunderstorms; however, they are associated with warmer low-level air, higher specific humidity and higher equivalent potential temperature (Figs. 6 and 7).

The composite vertical profiles of atmospheric variables for CFs with different flash counts in three seasons are shown in Fig. 7. In spring and fall, intense thunderstorms are found with higher $\Theta_{e}(\sim 8 \mathrm{~K}$ higher $)$ 


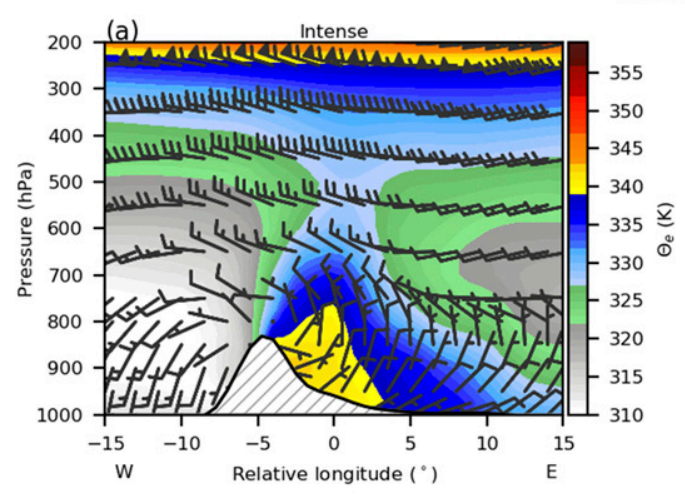

\section{ARGEN (DJF)}
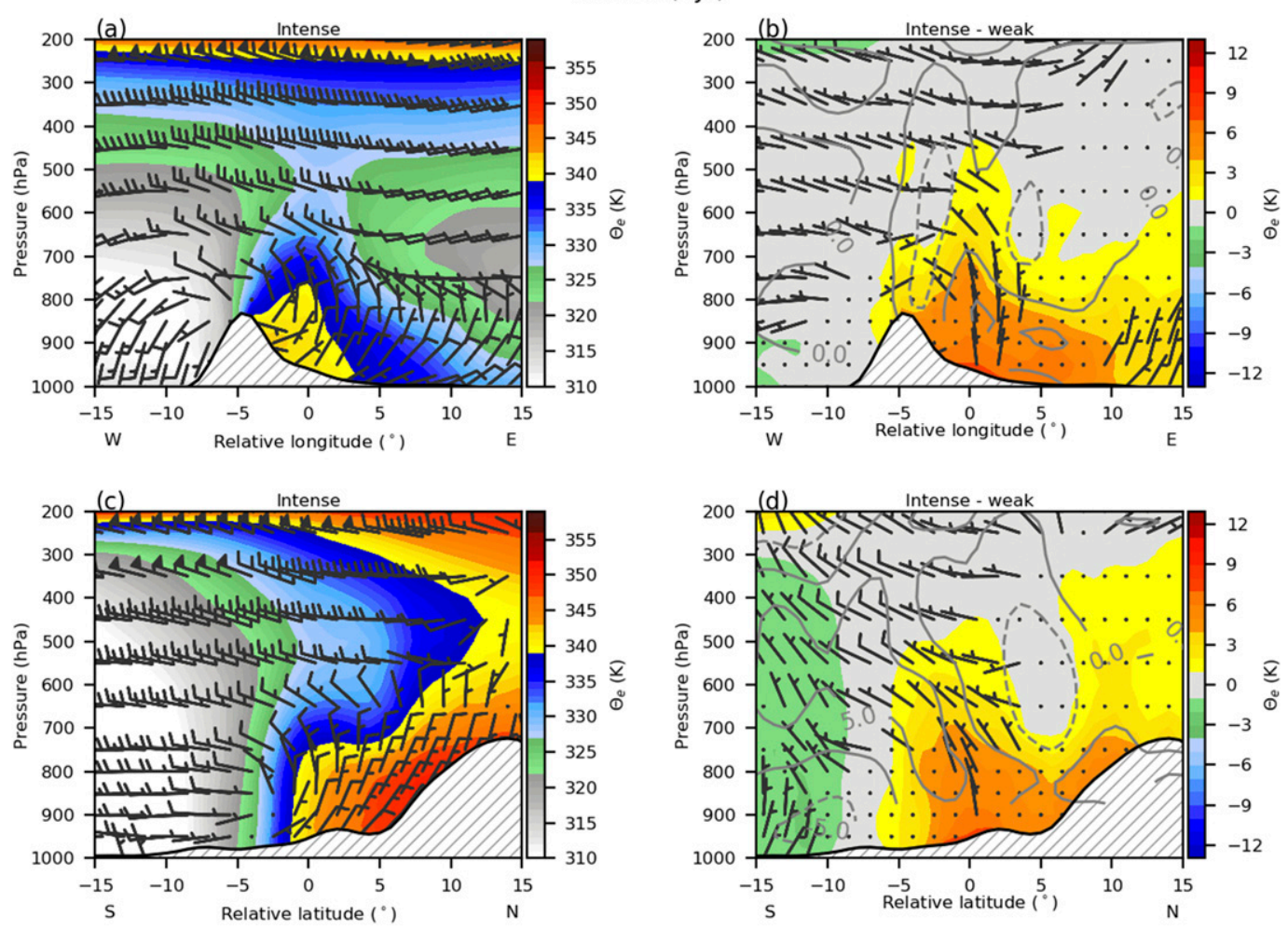

FIG. 9. As in Fig. 4, but for ARGEN during DJF.

at the low-level troposphere than weak thunderstorms. Previous studies found that the high- $\Theta_{e}$ air at low levels with its associated convective instability was essential for intense convection (Glass et al. 1995; Moore et al. 2003). The equivalent potential temperature increases rapidly with the onset of the summer monsoon in JJA (Fig. 7d). Mean near-surface $\Theta_{e}$ in JJA is $22 \mathrm{~K}$ higher than that in MAM (Figs. 7b,d), indicating a warmer and moister environment during the monsoon. Then it decreases with the retreat of the summer monsoon in SON (Fig. 7f).

\section{c. ARGEN (southern Cordoba and San Luis; DJF)}

With a high frequency of hail production (Cecil 2009; Cecil and Blankenship 2012) and intense convection (Liu and Zipser 2005; Zipser et al. 2006; Liu and Liu 2016), Argentina has been an understudied hotspot of the most intense thunderstorms in the world because of the lack of uniformity in the ground operational networks (Nascimento and Doswell 2006). Recently, the Remote Sensing of Electrification, Lightning, and Mesoscale/Microscale Process with Adaptive Ground Observations (RELAMPAGO; Mulholland et al. 2018) field campaign has collected unique observations of atmospheric and surface conditions to explore convective development over this region. The moisture-laden South America low-level jet (SALLJ) has been found to play a vital role in the development of convection over this region (Nieto Ferreira et al. 2003; Vera et al. 2006; Salio et al. 2007; Romatschke and Houze 2010). Rasmussen and Houze (2016) delineated a conceptual model in which they synthesized key factors of convection initiation in the lee of the subtropical Andes, including lee cyclone, topography, and moisture flux. In that model, the crucial role of orographic control in convective initiation was demonstrated using simulations with the Weather Research and Forecasting Model.

This section attempts to provide a comprehensive description of the environment of TRMM-LIS-identified intense thunderstorms over ARGEN. Figure 8 presents the composite large-scale conditions of intense thunderstorms over ARGEN in December-February. East of the Andes and north of the Sierras de Cordoba, the wind pattern contains several key features that have some similarity to those in SCUS that help explain the occurrence of intense convection over this region. A strong low-level northeasterly jet at low levels, the SALLJ, brings tropical moisture toward the storm centroid (Fig. 8b) extending from near surface to about 

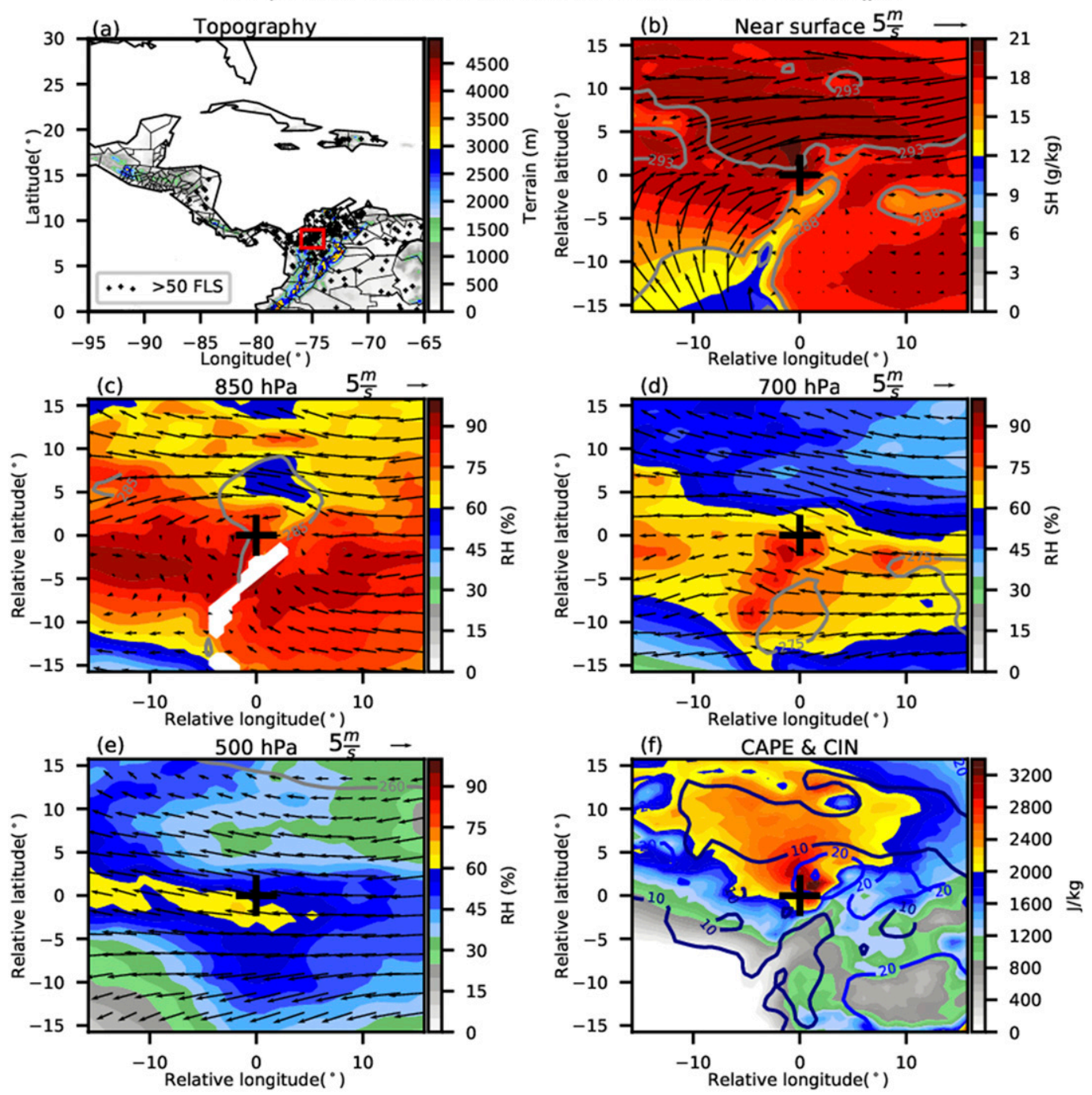

FIG. 10. As in Fig. 3, but for COLOM during JJA.

$700 \mathrm{hPa}$. The SALLJ is enriched in moisture by evapotranspiration in the Amazon basin (Marengo et al. 2004). Similar to the situation in SCUS, the low-level jet is very often capped by a stable layer separating it from dry, potentially warmer air descending in the westerly flow downstream of the Andes (Figs. 8c,d). At $500 \mathrm{hPa}$, the storm centroid is within the strong westerly wind with a weak trough in the lee side of the Andes (Fig. 8e). Intense thunderstorms are more likely to be found in regions of moderate CAPE $\left(>1500 \mathrm{~J} \mathrm{~kg}^{-1}\right)$ and moderate CIN, but notably, in strong gradients of both. This suggests that it is critical to consider both CAPE and CIN, and their gradients, to anticipate when and where intense convection may erupt.

Characterized by a northerly wind at low levels (below $700 \mathrm{hPa}$ ), the storm centroid is also normally contained within westerly wind at the upper levels (Figs. 9a,c). This sheared environment is favorable for intense convection (Altinger de Schwarzkopf and Rosso 1982; Weisman and Klemp 1982; Rosenfeld et al. 2006). The anomaly composite cross section shows that intense thunderstorms are associated with stronger warm moist advection than weaker storms (Figs. 9b,d).

\section{d. COLOM (northern Colombia; JJA)}

Colombia is a region known to have a high frequency of MCSs (e.g., Velasco and Frisch 1987; Mohr and Zipser 1996; Zipser et al. 2006; Durkee and Mote 2009), especially along the Pacific coast west of Colombia, which is one of the rainiest places on Earth (e.g., Lopez 1966; Poveda and Mesa 2000; Sakamoto et al. 2011; 

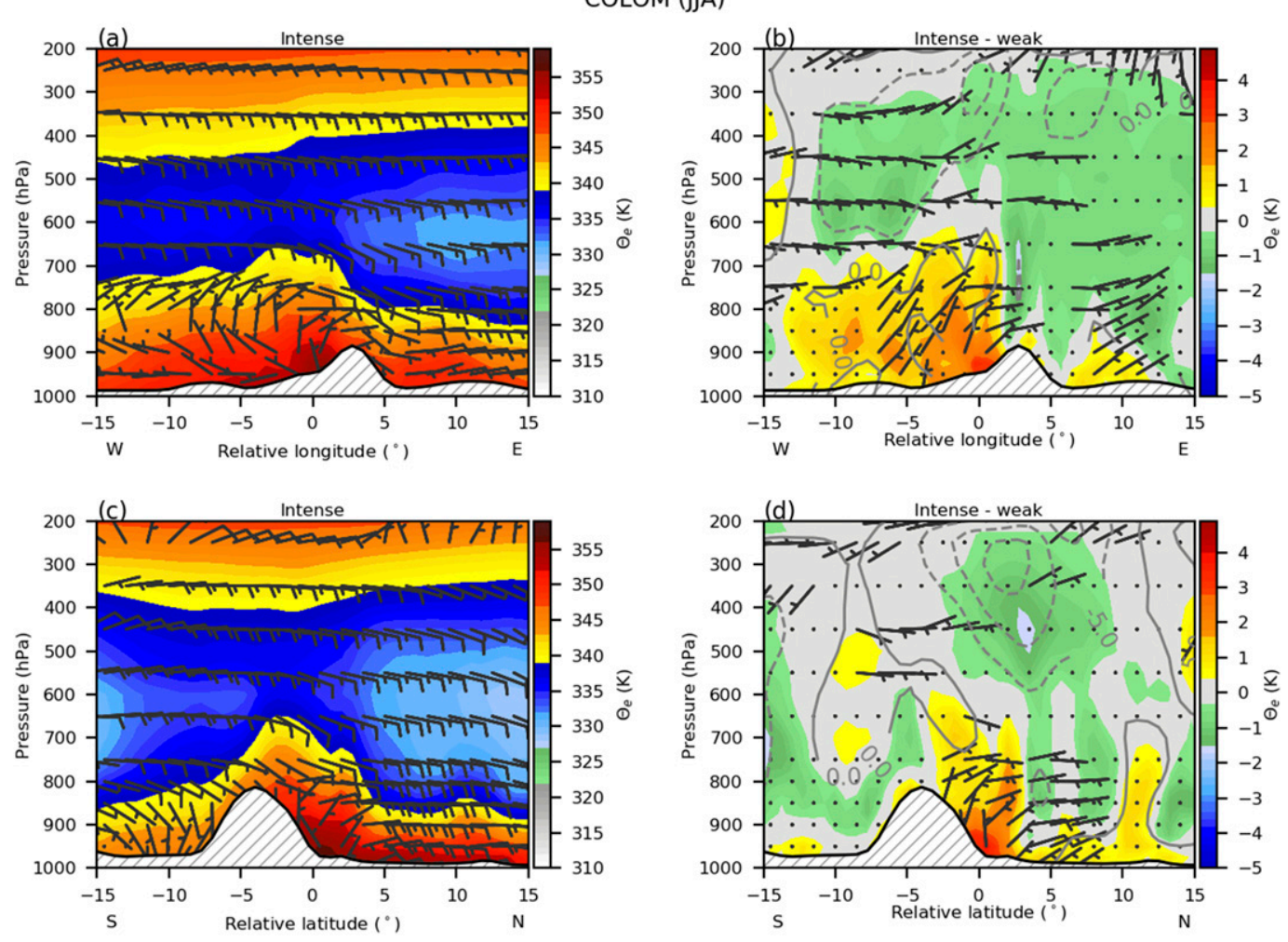

FIG. 11. As in Fig. 4, but for COLOM during JJA.

Durán-Quesada et al. 2012). In addition to the copious intense rainfall, Fig. 1 shows that the region, specifically northwest of Colombia, is another hotspot of high-frequency lightning, which is consistent with past studies (e.g., Christian et al. 2003; Zipser et al. 2006; Diaz et al. 2009; Cecil et al. 2015; Albrecht et al. 2016).

The composite large-scale conditions of intense thunderstorms in summer over this region is shown in Fig. 10. Wind flows near the surface from the south becoming westerly (known as the Chocó jet), which is associated with a strong sea surface temperature (SST) gradient between the coastal region of Colombia and Ecuador-Peru cold tongue (Poveda et al. 2006). This low-level flow transports air with high specific humidity from the Pacific Ocean into this region (Poveda and Mesa 2000; Mapes et al. 2003; Sakamoto et al. 2011; Zuluaga and Houze 2015). Meanwhile, the encounter of the Chocó jet with the easterly low-level jet, known as the Caribbean low-level jet (CLLJ) (Magaña et al. 1999; Amador and Magaña 1999), forms a strong convergence in the low troposphere. From 700 to $500 \mathrm{hPa}$, the wind is predominantly easterly and forms a strong wind shear with the nearsurface westerly Chocó jet. The intense convection over COLOM is characterized by a large CAPE $\left(>2000 \mathrm{~J} \mathrm{~kg}^{-1}\right)$ center and exhibits relatively small CIN $\left(\sim 20 \mathrm{~J} \mathrm{~kg}^{-1}\right)$. Again, important factors including the convergence, the complex topography, and the abundant moisture in the low troposphere make this region a favorable place for the development of thunderstorms. In addition, Zuluaga and Houze (2015) pointed out that the diurnal heating also plays an important role in the development of convection over this region.

Figures $11 \mathrm{a}$ and $11 \mathrm{c}$ shows that thunderstorms in this region experience appreciable wind shear between low and upper levels. The composite cross section also shows that the low-level jet is below $800 \mathrm{hPa}$ and relatively shallower than in other regions. Compared to weak thunderstorms, intense thunderstorms are also found associated with higher $\Theta_{e}$ at low levels over this region. However, the differences between intense and weak thunderstorms in this region are relatively small compared to those over the ARGEN and HIMA (Figs. 11b,d). Note that the large-scale conditions of weak storms are removed when they are coincidence with intense ones. There is possibility that the large-scale environments of weak storms might not be pure "weak thunderstorms" 
Composite of ERA-Interim for CFs with $>50$ flashes in SAHEL (JJA)
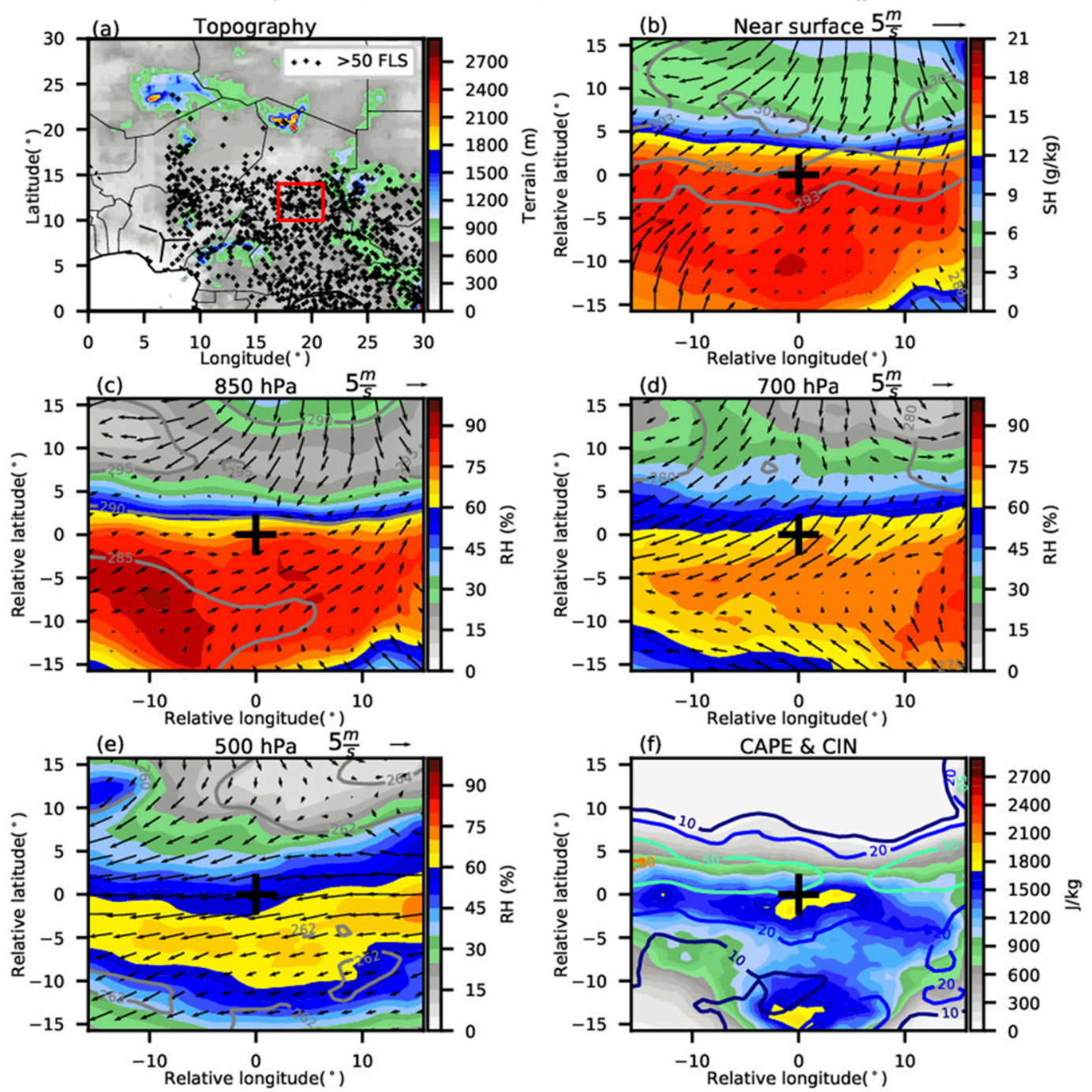

FIG. 12. As in Fig. 3, but for SAHEL during JJA.

when weak storms occur close to an intense one that is just outside of the TRMM overpasses. This might contribute to the similarity of environment for lowand high-flash-rate thunderstorms.

\section{e. SAHEL (southern Chad; JJA)}

SAHEL, a transition zone between moist tropical regions near the Guinean coast and the precipitationfree Sahara, has received a great deal of attention because of the highly favorable meteorological conditions for the development of convection (e.g., Tetzlaff and Peters 1988; Parker et al. 2005; Lafore et al. 2011; Zuluaga and Houze 2015). In Fig. 12, the boundary between the hot, dry air from the Sahara and moist air south of the storm centroid is evident near the surface (Fig. 12b). Hubert (1926) has defined the confrontation of the two air masses as intertropical front with respect to the surface intertropical convergence zone (ITCZ; Nicholson 2018). South of the storm centroid the flow is from the southwest. The boundary shifts northward with height. At $700 \mathrm{hPa}$, the main feature is the African easterly jet (AEJ) with strong wind shear between low levels and $700 \mathrm{hPa}$ (Fig. 12d). This low-level shear could fundamentally affect the intensity of convection, as has been emphasized by Alfaro (2017). At $700 \mathrm{hPa}$, the storm centroid is found in the northerly phase of the African easterly waves (AEWs), which are a result of the instability of the AEJ (Burpee 1972). The AEWs are also visible at $500 \mathrm{hPa}$, but slightly shift to the north (Fig. 12e). The role of the westward traveling AEWs over this region in the development of the convective activity 
SAHEL (JJA)
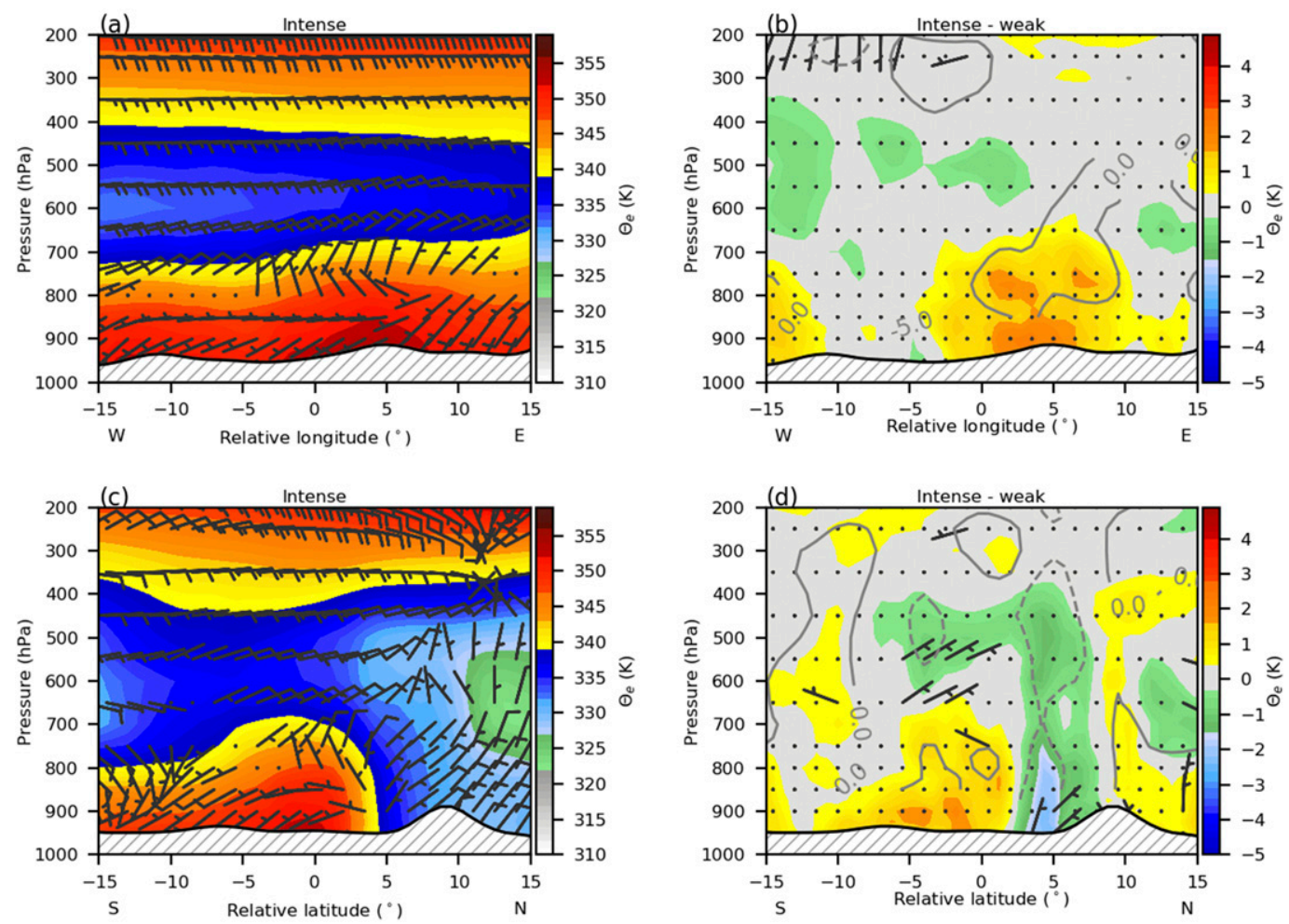

FIG. 13. As in Fig. 4, but for SAHEL during JJA.

is well studied (e.g., Carlson 1969; Burpee 1972; Aspliden et al. 1976; Fink and Reiner 2003; Guy and Rutledge 2012). Recent studies indicate that convection in central and eastern Africa may play a role in triggering the AEW activity (Berry and Thorncroft 2005; Mekonnen et al. 2006; Price et al. 2007). The transition region between the Sahara Desert and the vegetated region of central Africa has strong meridional gradients of CAPE and CIN (Fig. 12f). During the active season of the West African monsoon (June-September), the moist air is beneath the relatively hot dry air from the Saharan Desert. Convection could be triggered once the potential instability is released, for example, by ascent ahead of the AEWs trough.

Wind direction changing from westerly at the low level to easterly at the upper level indicate the strong wind shear over SAHEL region when intense convection occurs (Fig. 13a). The relatively low $\Theta_{e}$ in the mid- to upper troposphere in the cross section indicates that the air in this layer is dry (Fig. 13a). Roca et al. (2005) suggested that the dry intrusion in the Sahelian midtroposphere originate from the anticyclonic flank of the polar jet stream. In their case study, the dry-air intrusion can have RH less than
$5 \%$. Several studies have described the important role of dry-air intrusion in convective activity (Brown and Zhang 1997; Johnson et al. 2001; Roca et al. 2005). The relatively high $\Theta_{e}$ values $(>335 \mathrm{~K})$ in the whole column south of storm (Fig. 13b) is consistent with the theory, proposal by Nicholson (2009) and other researchers (e.g., Brubaker et al. 1993; Savenije 1995; Trenberth 1999), that the moisture over West Africa is locally recycled. In addition to slightly drier middle troposphere and higher $\Theta_{e}$ at low levels for intense thunderstorms, a larger gradient in $\Theta_{e}$ is found for intense thunderstorms than weak ones (Fig. 13d).

\section{f. CONGO (northern Democratic Republic of the Congo; $M A M)$}

As one of the places that are vulnerable to climate variability and extreme events, the Congo basin is one of the regions that experience the highest frequencies of lightning and thunderstorms (Christian et al. 2003; Zipser et al. 2006; Cecil et al. 2015). According to the global ranking of lightning-flashrate density reported by Albrecht et al. (2016), half of the world's hottest spots in lightning are found in the Congo basin. The Congo basin is also the region with a small seasonal variation in the percentage of 
Composite of ERA-Interim for CFs with $>50$ flashes in CONGO (MAM)
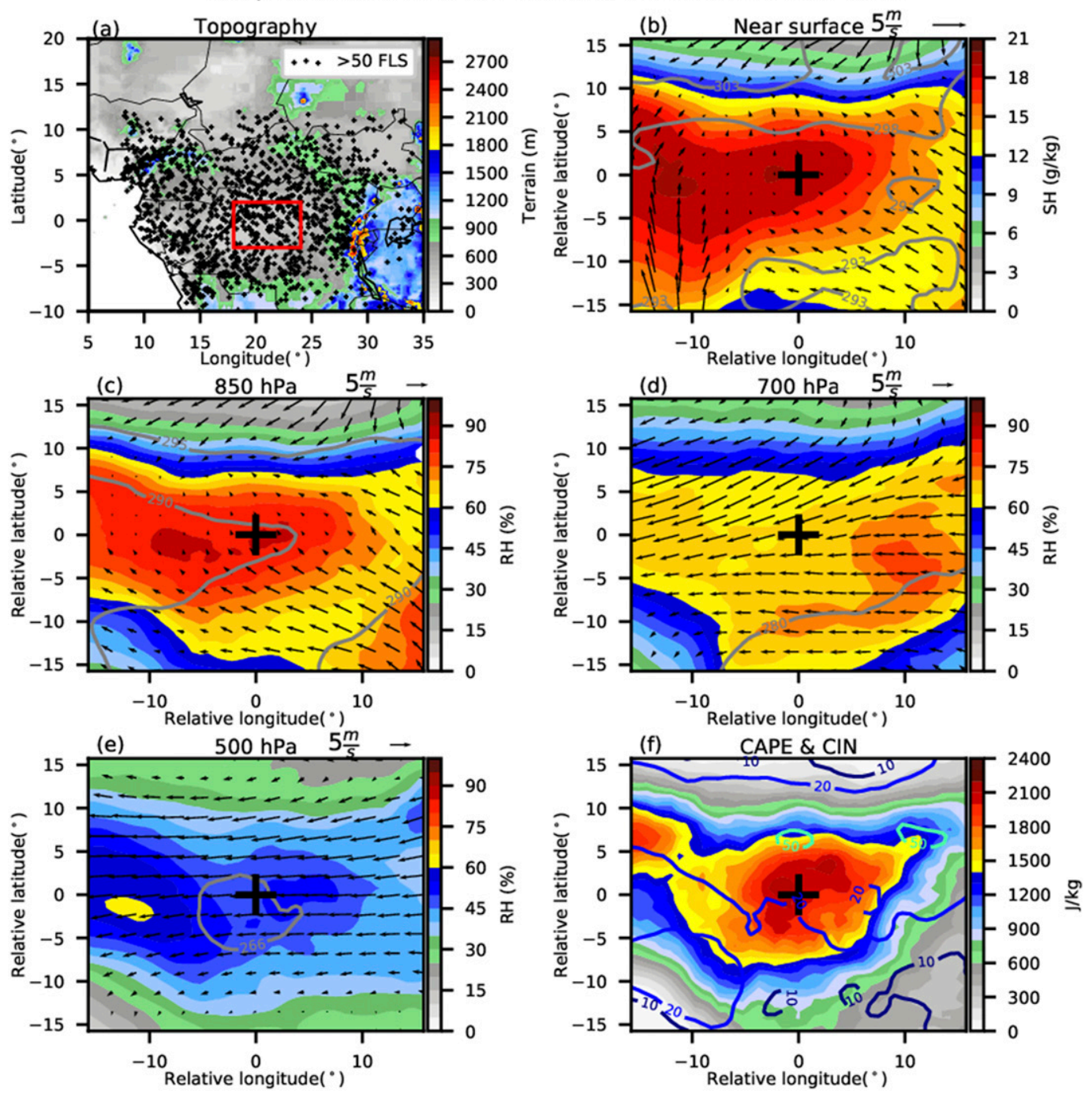

FIG. 14. As in Fig. 3, but for CONGO during MAM.

intense thunderstorms among the selected regions in this study (Fig. 2). Three major monsoons, the northeast, southeast, and southwest monsoon described by Nicholson $(1996,2018)$, play a crucial role in the convection and rainfall over this region. However, the favorable large-scale environments for intense thunderstorms is not yet fully understood over this region due to very limited observations.

Located in the same longitude zone as SAHEL, there are a lot of similarities in the large-scale conditions for intense convection over CONGO and SAHEL. Three major airstreams, dry air from the northeast, air from the southeast at levels below $700 \mathrm{hPa}$, and moist southerly flow, are found near the surface (Fig. 14b). The convergence zone of the three airstreams is found at around $5^{\circ}$ relative latitude and is associated with the "tropical rainbelt," termed by Nicholson (2009). The near-surface convergence is located north of the storm centroid, compared to that over SAHEL. Consistent with previous studies, divergence of the mountain breezes over the surrounding highlands is found near the storm centroid (Jackson et al. 2009; Nicholson 2018). The southerly monsoon confined to the lowest levels (Figs. 14b,c) of the troposphere is similar to the results shown by Nicholson (2009). Sufficient moisture from the Congo rain forest makes the Congo basin unstable yearround (Reason et al. 2006). The easterly wind is dominant at the middle and upper levels. Large CAPE but small CIN values (Fig. 14f) make it easy for air to rise to the level of free convection and release the potential energy. Thermodynamic instability in warm 


\section{CONGO (MAM)}
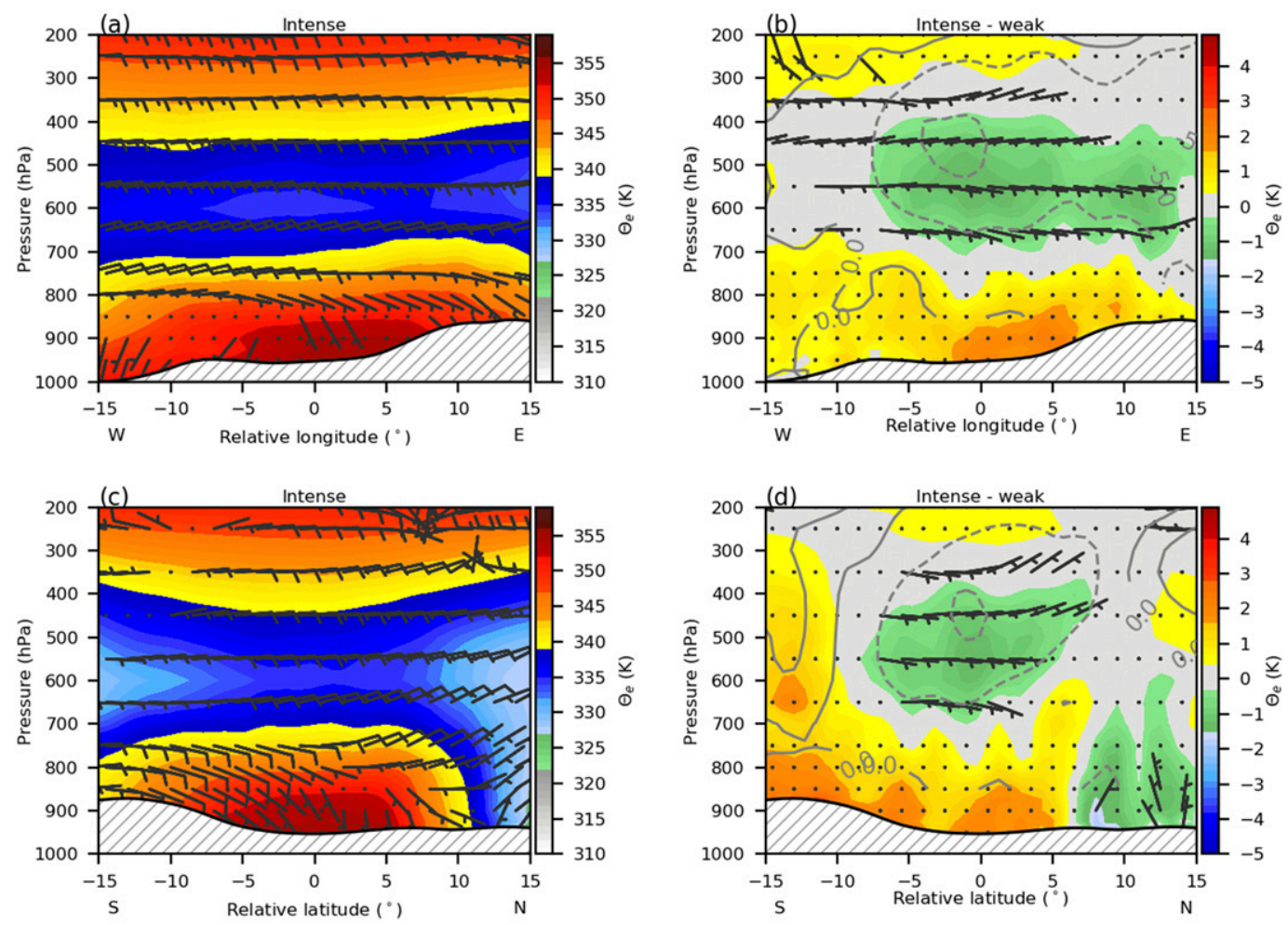

FIG. 15. As in Fig. 4, but for CONGO during MAM.

and humid air, as well as ascent facilitated by the surface wind convergence, make this region active with intense thunderstorms. The stronger easterly flow and the drier middle to upper troposphere (Figs. 15b,d) are consistent with the results shown by Chaggar (1977), that stronger easterly flow is more conducive to the development of intense thunderstorms over eastern Africa. Due to limited observations over CONGO, the quality of reanalysis must be considered in interpreting the results over this region. Also, as one of the hotspots of thunderstorms, the preconvection environments we selected could be potentially modified by the thunderstorms.

\section{g. NWM (Chihuahua region; JJA)}

The western slope of the Sierra Madre Occidental east of the Gulf of California (Fig. 16a), in northwestern Mexico is another hotspot of intense thunderstorms (Fig. 1). NWM receives more than $60 \%$ of its total annual rainfall in the burst of convective activity during the North American monsoon (NAM) (Douglas et al. 1993), which typically begins in mid-June and finishes around the end of September (Higgins et al. 1997).

The outstanding thermodynamic feature near the surface is the surge of moisture from the Gulf of
California (Fig. 16b). Suggested by prior studies (Hales 1972; Brenner 1974; Stensrud et al. 1997), coastally trapped, northward-propagating disturbances are characterized by anomalous southerly or southeasterly moisture flow along the Gulf of California. Low-level moisture transport may play an important role in the onset of the NAM convection, which has been emphasized in numerous studies (e.g., Green and Sellers 1964; McCollum et al. 1995; Romatschke and Houze 2010). An anticyclone is faintly identifiable at $700 \mathrm{hPa}$ and becomes clear at $500 \mathrm{hPa}$ (Figs. 16d,e). The anticyclone is another well-known feature associated with the NAM convection. Evidence shows that deep convection is related to the forming of the NAM anticyclone (e.g., Newman and Johnson 2012; Stensrud 2013). Prior studies have also demonstrated that the convergence and upward motion associated with the passage of easterly waves or anticyclones often facilitate convective storms (Bieda et al. 2009; Finch and Johnson 2010; Newman and Johnson 2012).

In addition to the features shown, several characteristics are worth mentioning in Fig. 16. The strong specific humidity gradient and the convergence near the coast in Fig. 16b confirms that the Gulf of California is the major moisture source for the NAM convection instead of the 
Composite of ERA-Interim for CFs with $>50$ flashes in NWM (JJA)
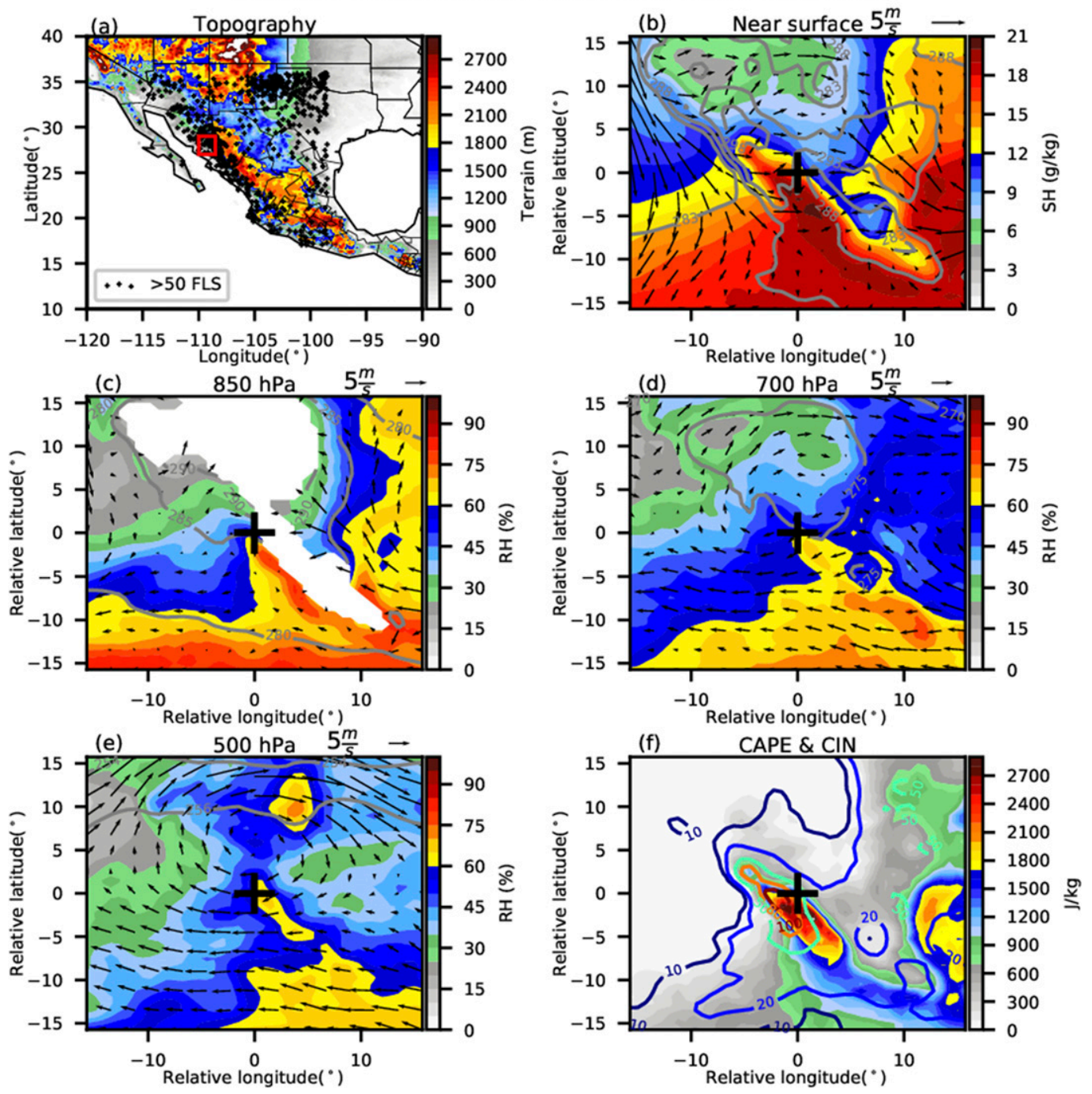

FIG. 16. As in Fig. 3, but for NWM during JJA.

Gulf of Mexico due to the topography (Anderson and Roads 2001; Berbery 2001; Bordoni and Stevens 2006; Barron et al. 2012). Convergence between the northwesterly and southeasterly wind along the high terrain is apparent near the surface. As many authors have detailed, this is largely controlled by a combination of the sea breeze and the topography of the Sierra Madre Occidental during afternoon and evening. The leading edge of the sea breeze is often associated with sharp changes in temperature and moisture but not captured by reanalysis in the figures. It could take on characteristics similar to those of synopticscale cold fronts (e.g., Simpson et al. 1977; Miller et al. 2003). The combination of moisture from the marine air and surface heating from the land make the region particularly favorable for convection, which has been documented in an abundant literature (e.g., Byers and
Rodebush 1948; Burpee and Lahiff 1984; Blanchard and Lopez 1985; Nicholls et al. 1991; Pielke et al. 1991). Johnson et al. (2007) showed that the onshore flow associated with the notable sea breeze along the east coast of the Gulf of California also affects the maximum convection and precipitation over the slope of the Sierra Madre Occidental. The storm centroid is found east of the maximum CAPE and CIN centers (Fig. 16f). As shown in Fig. 17, high $\Theta_{e}$ at low levels $(>340 \mathrm{~K})$ suggests warm moist air surges from the gulf. A stronger low-level wind shear is found for intense thunderstorms than weak ones.

\section{h. Similarities and differences among the thermodynamic and dynamic conditions}

Up to this point, we have explored the key properties of the large-scale conditions for the TRMM-LIS-identified 


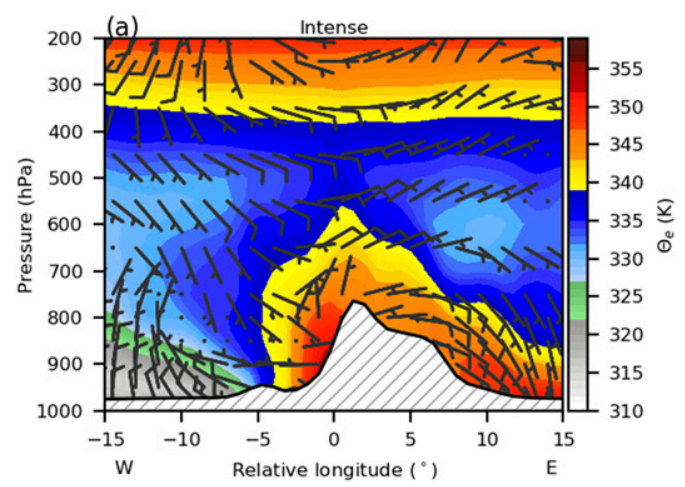

NWM (JJA)
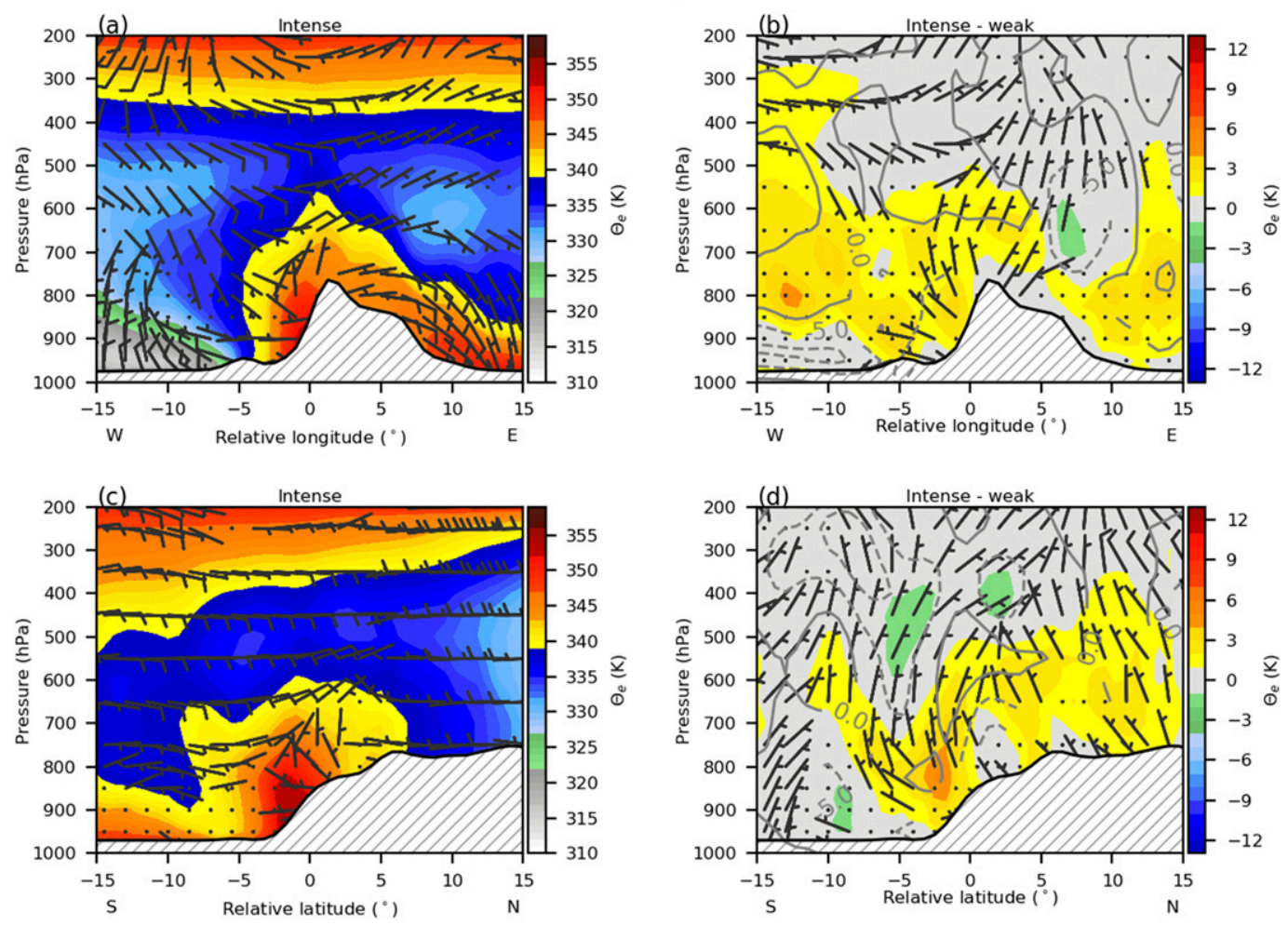

FIG. 17. As in Fig. 4, but for NWM during JJA.

intense thunderstorms over seven selected regions. The large-scale conditions related to intense thunderstorms over these regions bear some similarities; however, intense thunderstorms are creations of environments whose properties may vary greatly in time and space.

For example, Fig. 18 shows the composite soundings of weak and intense thunderstorms over HIMA in three different seasons. Intense thunderstorms in spring (MAM) and fall (SON) exhibit a colder and dryer air at low levels than in summer (JJA). In MAM and SON, intense thunderstorms have warmer and moister tropospheric environments than weak ones. Among the three seasons, JJA has the weakest upperlevel westerly wind. With the onset of monsoon, the sounding of intense thunderstorms in JJA is found to be associated with the largest CAPE but the smallest $\mathrm{CIN}$, as well as the highest level of neutral buoyancy. Though the upper troposphere is less important in the initiation of convection, JJA intense thunderstorms have much dryer air in the midtroposphere than other two seasons. The level of neutral buoyancy (LNB) over HIMA in JJA could reach $200 \mathrm{hPa}$, which helps explain why the deepest convection occurs frequently there (Weston 1972; Zipser et al. 2006; Romatschke et al. 2010). Note that the surface pressure between weak and intense CFs is also different. This indicates that the centroids of CFs might be selected at different elevations.

To summarize the favorable environments of the thunderstorms over the seven regions, the mean values of the thermodynamic and dynamic parameters and the numbers of weak and intense thunderstorms are listed in Table 2. Those parameters include CAPE, CIN, SHEAR $_{1-6 \mathrm{~km}}$, near-surface SH (SHL), midlevel RH (RHM; 700-500 hPa), lifting condensation level (LCL), and $\mathrm{SRH}_{1-3 \mathrm{~km}}$. The composite soundings (Fig. 19) and the box-and-whisker plots of four selected atmospheric parameters over different regions (Fig. 20) are also shown to compare the similarities and differences among those favorable environments.

Among these variables, substantially higher CAPE values are found in tropical regions (COLOM, SAHEL, CONGO, and NWM) than that in subtropical regions (HIMA, SCUS, and ARGEN). However, CIN, wind shear between 1 and $6 \mathrm{~km}$ above the surface $\left(\mathrm{SHEAR}_{1-6 \mathrm{~km}}\right)$, and storm-relative helicity between 1 and $3 \mathrm{~km}$ above the surface $\left(\mathrm{SRH}_{1-3 \mathrm{~km}}\right)$ in the subtropical regions are relatively larger than those in the tropical regions. This is true for both intense and weak CFs. Larger CAPE but smaller CIN are found over CONGO and 

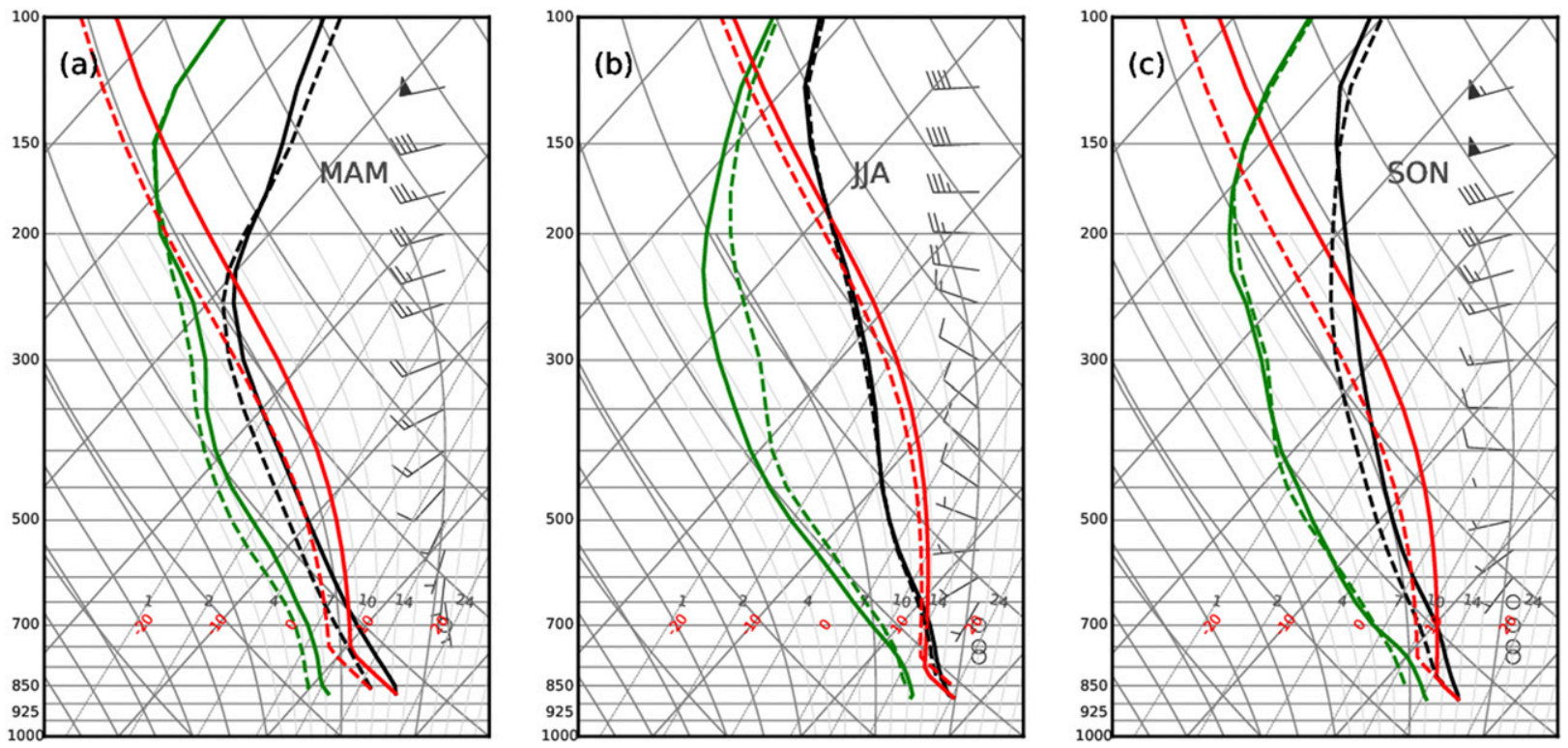

FIG. 18. Composite soundings for CFs with 1-3 flashes (dashes lines) and $>50$ flashes (solid lines) over HIMA during (a) MAM, (b) JJA, and (c) SON. The wind barbs are for CFs with $>50$ flashes. Temperature is shown in black lines, dewpoint temperature in green lines, and temperature of lifted most unstable parcels from near the surface in the red lines.

COLOM than other selected regions. SCUS has a relatively smaller CAPE than the other selected regions. This is consistent with the composite soundings as shown in Fig. 19. In tropics, SAHEL has larger wind shear and storm-relative helicity values that is close to subtropical regions (Fig. 20 and Table 2). In terms of surface specific humidity and the height of the LCL, the main outliers are HIMA in Spring and NWM, where orographic lifting allow intense storms developing in rather dry surface environments with LCL greater than $2.3 \mathrm{~km}$ above the surface, in contrast to lower LCL $(<1.3 \mathrm{~km})$ in all other regions. Note that some profiles, selected using nearest ERA-Interim grid point, may not be representative over the terrain with sharp gradients in HIMA and NWM. Midlevels are rather dry (RH in the $51 \%-71 \%$ range) for all seven regions.

Next, comparing the environmental properties for intense versus weak thunderstorms in each region, there is generally more discrimination in the subtropics, with all three regions showing much larger CAPE, modestly larger shear and larger helicity for the intense CFs, compared with the low-flash-rate CFs. Consistent with the larger CAPE, the subtropical regions also show larger near-surface specific humidity for intense versus weak storms. For tropical regions, with the exception of larger CAPE for intense versus weak storms, and slightly larger shear, the remaining parameters (humidity near the surface and in midlevels and the LCL), show very small differences, suggesting either that these parameters are poor discriminators in these tropical regions, or that the reanalyses may not be sufficiently reliable to draw conclusions.

Many observational and modeling studies have clarified the relationship between the storm longevity and propagation and the character of the hodograph associated with the vertical shear (e.g., Maddox 1976; Weisman and Klemp 1982; Thompson et al. 2007), although debate continues about the effects of the curvature on the characteristic of supercell storms (Weisman and Rotunno 2000). The hodographs related to the intense thunderstorms over seven regions are shown in Fig. 21. Sitting under the westerly jet, the difference in the structure of hodographs over ARGEN, HIMA, and SCUS is distinct from other regions. The composite hodograph is substantially curved in the lowest layers with large shear between low and midlayers over ARGEN, SCUS and HIMA. Low-level wind speeds and $\mathrm{SRH}_{\text {sfc-6km }}$ are strongest for SCUS. The wind shear over SAHEL, although only slightly curved is fairly strong between the surface to $700 \mathrm{hPa}$. CONGO, COLOM, and NWM are characterized by relatively small wind shear in the low levels. With different low-level shear scenario, the role of shear in organizing the convection varies significantly from one region to another.

\section{Summary and discussion}

The goal of the current study is to explore the regional variations of relationships between intense thunderstorms 

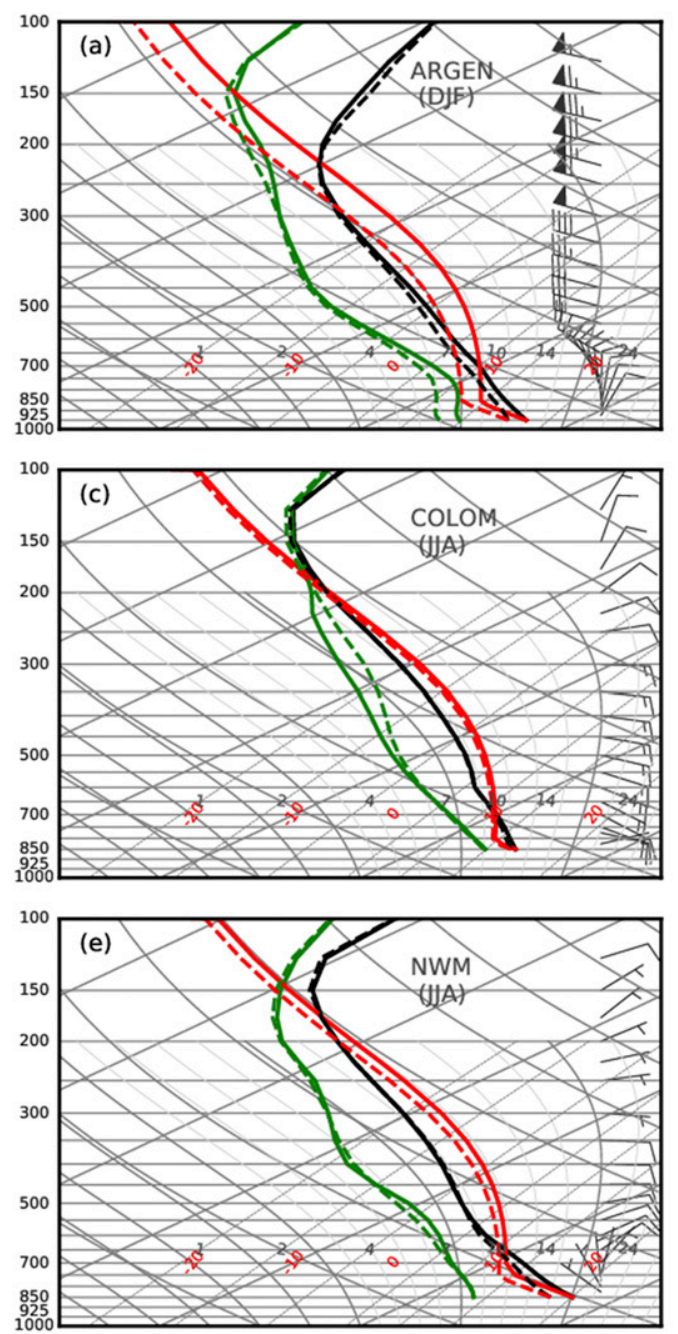
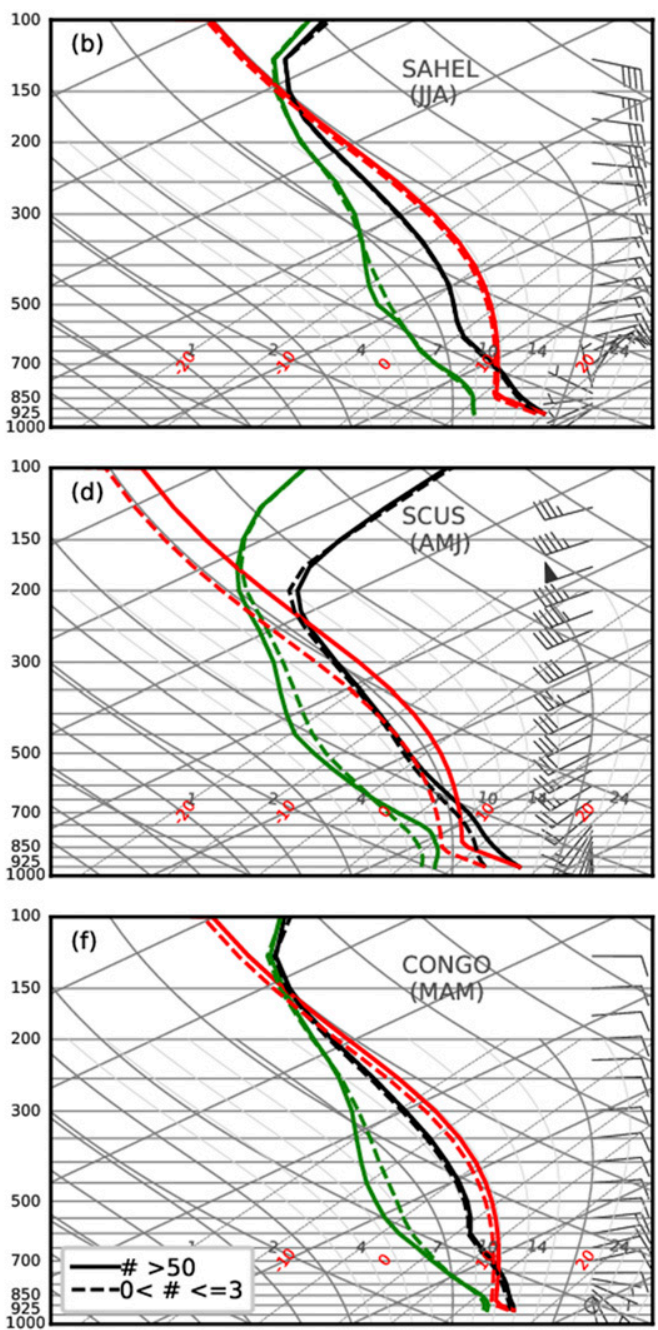

FIG. 19. Composite soundings for CFs with 1-3 flashes (dashes lines) and $>50$ flashes (solid lines) during the warm season over different regions: (a) ARGEN during DJF, (b) SAHEL during JJA, (c) COLOM during JJA, (d) SCUS during AMJ, (e) NWM during JJA, and (f) CONGO during MAM. The wind barbs are for CFs with $>50$ flashes. Temperature is shown in black lines, dewpoint temperature in green lines, and temperature of lifted most unstable parcels in the red lines.

and their favorable thermodynamic and kinematic environments. These environments have been documented using ERA-Interim data for seven hotspot regions with intense TRMM-observed convective features. Based on the composite fields for high-flash-rate thunderstorms, we have compared these seven regions, seeking to learn whether their environments share common features, and within each region, we have also compared low- versus high-flash-rate storms.

The common ingredients for intense convection found in previous studies (e.g., McNulty 1978; Johns and Doswell 1992; Doswell et al. 1996), abundant low-level moisture, convective instability as indicated by large CAPE, and some lifting mechanism to permit the ascent of parcels through a layer of convective inhibition to their level of free convection, are found over all seven regions. However, some of the details, such as the magnitudes of the low- to midlevel wind shear, CAPE, CIN, the specific lifting mechanisms, and the role of topography, vary considerably from region to region, especially between the tropical and subtropical regions. The major conclusions of this study are summarized as follows:

- The magnitude of the low-midtroposphere wind shear is greatest over SCUS, ARGEN, SAHEL, and HIMA, implying that its effect on the intensity of storms over those regions is consistent with prior studies (e.g., Weisman and Klemp 1982; Schoenberg Ferrier et al. 1996; Takemi 2007; Tao et al. 2007). But the intense 

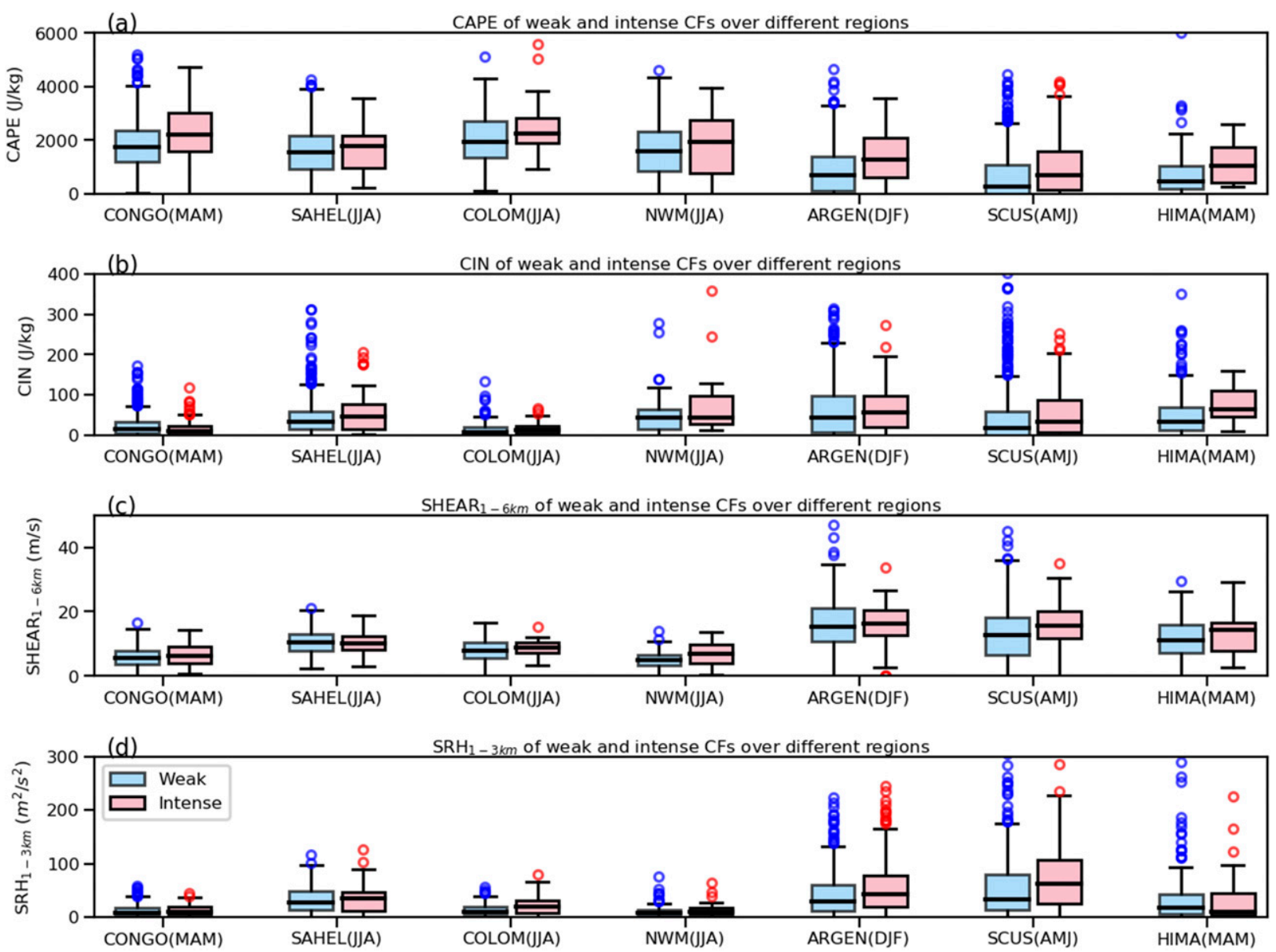

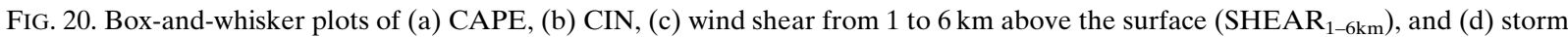
relative helicity from 1 to $3 \mathrm{~km}$ above the surface $\left(\mathrm{SRH}_{1-3 \mathrm{~km}}\right)$ for weak (light blue) and intense (pink) CFs over different regions. The thick line denotes the median, and the box outlines the 25 th and 75 th percentiles. The small circles represent outliers.

storms over other regions, with far lower wind shear, apparently gain their intensity without this mechanism. Relatively speaking, higher CAPE, lower CIN, and weaker low-level wind shear and helicity are found for thunderstorms over tropical regions than subtropical regions. The only selected region to combine both high CAPE and strong wind shear is SAHEL.

- Within each specific region, comparing weak versus intense storms (i.e., low- vs high-flash-rate storms) gives widely differing results. The three subtropical regions share many similarities with the abundantly studied south-central United States, but the tropical regions are more varied. For example, compared to weak storms, intense storms in subtropical regions and SAHEL have much greater CAPE and greater shear. In tropical regions, strong storms have greater CAPE than weak storms but the differences are not as great as those in the subtropical regions. For low-level specific humidity, the differences between weak and intense storms in the tropics appear to be insignificant compared to the rather strong differences in the subtropics.

- The specific role played by topography appears to vary from region to region, although there is little question of its importance. The Rockies and Andes both provide opportunities for sinking of midlevel flow on their lee side, helping to create the cap (CIN) overlying the region of high CAPE, permitting stronger storms when the convergence associated with the low-level jet provides the required lift to assist in breaking through that cap. In HIMA, NWM, and COLOM, in contrast, the mountains appear to provide the lifting mechanism directly. Note that mesoscale (and smaller scale) factors, such as mountain-valley flows, differential heating, and sea breezes would not be captured by the reanalysis used here.

To the extent that the environment of intense storms in these regions shares conditions widely agreed to be important, the differences between weak and intense 


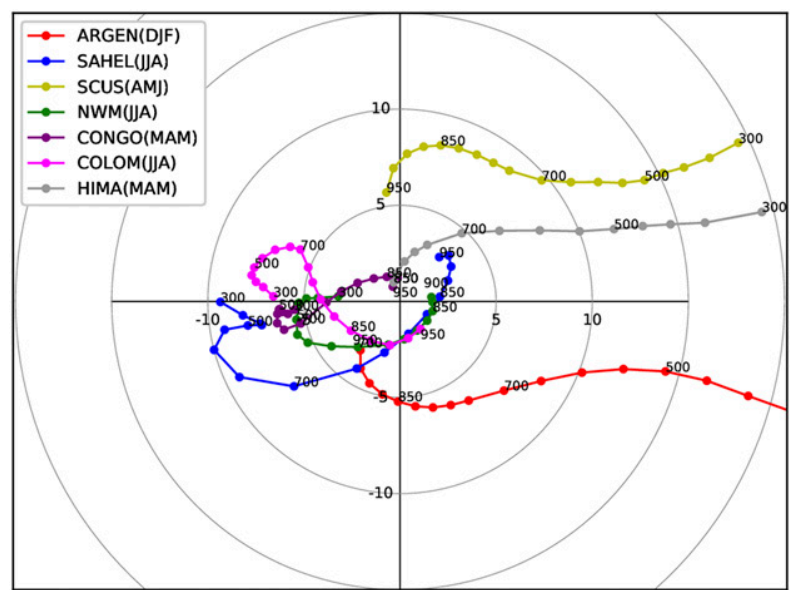

FIG. 21. Composite hodograph of intense CFs with $>50$ flashes during the warm season over different regions.

storms in some regions, especially the tropical regions, and the variability from region to region, demands some caution in accepting these results uncritically. First, the composite fields might smooth out some unique details across cases by averaging. Though the conditions prior to the CF time is used in this study, ERA-Interim is probably not completely independent of the impact of intense convection itself. Moreover, there are uncertainties of unknown quantity in the reanalysis datasets, making rigorous and unambiguous comparison between weak and intense storms difficult. The accuracy of ERAInterim in data-sparse regions, especially in regions with complex topography (COLOM, NWM, HIMA) can certainly be questioned. Also, we have not considered other factors, such as the nature of synoptic disturbances in data-sparse regions, or potential aerosol effects, so we look forward to future studies, with improved datasets, before accepting these results in quantitative detail.

Acknowledgments. We thank Dr. Daniel Cecil for his comments on an early version of this manuscript, and we are especially appreciative of the constructive suggestions from the three anonymous reviewers. This research was supported by NASA Precipitation Measurement Mission Grants NNX17AI99G and 80 NSSC19K0673 under the direction of Dr. Gail Jackson and NNX16AH74G under the direction of Dr. Erich Stocker. Thanks to the Precipitation Processing System (PPS) team at NASA Goddard Space Flight Center, Greenbelt, Maryland, for data processing assistance.

\section{REFERENCES}

Albrecht, R. I., S. J. Goodman, D. E. Buechler, R. J. Blakeslee, and H. J. Christian, 2016: Where are the lightning hotspots on
Earth? Bull. Amer. Meteor. Soc., 97, 2051-2068, https:// doi.org/10.1175/BAMS-D-14-00193.1.

Alcala, C. M., and A. E. Dessler, 2002: Observations of deep convection in the tropics using the Tropical Rainfall Measuring Mission (TRMM) Precipitation Radar. J. Geophys. Res., 107, 4792, https://doi.org/10.1029/2002JD002457.

Alfaro, D. A., 2017: Low-tropospheric shear in the structure of squall lines: Impacts on latent heating under layer-lifting ascent. J. Atmos. Sci., 74, 229-248, https://doi.org/10.1175/JASD-16-0168.1.

Allen, D. J., and K. E. Pickering, 2002: Evaluation of lightning flash rate parameterizations for use in a global chemical transport model. J. Geophys. Res., 107, 4711, https://doi.org/10.1029/ 2002JD002066.

Altinger de Schwarzkopf, M. L., and L. C. Rosso, 1982: Severe storms and tornadoes in Argentina. Preprints, 12th Conf. on Severe Local Storms, San Antonio, TX, Amer. Meteor. Soc., 59-62.

Amador, J. A., and V. Magaña, 1999: Dynamics of the low level jet over the Caribbean Sea. Preprints, Third Conf. on Hurricanes and Tropical Meteorology, Dallas, TX, Amer. Meteor. Soc., 868-869.

Anderson, B. T., and J. O. Roads, 2001: Summertime moisture divergence over the southwestern US and northwestern Mexico. Geophys. Res. Lett., 28, 1973-1976, https://doi.org/ 10.1029/2001GL012903.

Aspliden, J. P., Y. Tourre, and J. B. Sabine, 1976: Some climatological aspects of West African disturbance lines during GATE. Mon. Wea. Rev., 104, 1029-1035, https://doi.org/ 10.1175/1520-0493(1976)104<1029:SCAOWA > 2.0.CO;2.

Atkins, N. T., R. M. Wakimoto, and C. L. Ziegler, 1998: Observations of the finescale structure of a dryline during VORTEX 95. Mon. Wea. Rev., 126, 525-550, https://doi.org/ 10.1175/1520-0493(1998)126<0525:OOTFSO $>2.0 . C O ; 2$.

Barnes, S. L., and C. W. Newton, 1986: Thunderstorms in the synoptic setting. Thunderstorm Morphology and Dynamics, 2nd ed. E. Kessler, Ed., University of Oklahoma Press, 75-112.

Barron, J. A., S. E. Metcalfe, and J. A. Addison, 2012: Response of the North American monsoon to regional changes in ocean surface temperature. Paleoceanography, 27, PA3206, https:// doi.org/10.1029/2011PA002235.

Barros, A. P., and T. J. Lang, 2003: Monitoring the monsoon in the Himalayas: Observations in central Nepal, June 2001. Mon. Wea. Rev., 131, 1408-1427, https://doi.org/10.1175/ 1520-0493(2003)131<1408:MTMITH>2.0.CO;2.

Barthe, C., W. Deierling, and M. C. Barth, 2010: Estimation of total lightning from various storm parameters: A cloud-resolving model study. J. Geophys. Res., 115, D24202, https://doi.org/ 10.1029/2010JD014405.

Basarab, B. M., S. A. Rutledge, and B. R. Fuchs, 2015: An improved lightning flash rate parameterization developed from Colorado DC3 thunderstorm data for use in cloud-resolving chemical transport models. J. Geophys. Res. Atmos., 120, 9481-9499, https://doi.org/10.1002/2015JD023470.

Beebe, R. G., 1958: An instability line development as observed by the tornado research airplane. J. Meteor., 15, 278-282, https://doi.org/10.1175/1520-0469(1958)015<0278:AILDAO > 2.0.CO;2.

Benjamin, S. G., and T. N. Carlson, 1986: Some effects of surface heating and topography on the regional severe storm environment. Part I: Three-dimensional simulations. Mon. Wea. Rev., 114, 307-329, https://doi.org/10.1175/1520-0493(1986) $114<0307:$ SEOSHA $>2.0 . \mathrm{CO} ; 2$ 
Berbery, E. H., 2001: Mesoscale moisture analysis of the North American monsoon. J. Climate, 14, 121-137, https://doi.org/ 10.1175/1520-0442(2001)013<0121:MMAOTN>2.0.CO;2.

Berry, G. J., and C. Thorncroft, 2005: Case study of an intense African easterly wave. Mon. Wea. Rev., 133, 752-766, https:// doi.org/10.1175/MWR2884.1.

Bieda, S. W., C. L. Castro, S. L. Mullen, A. C. Comrie, and E. Pytlak, 2009: The relationship of transient upper-level troughs to variability of the North American monsoon system. J. Climate, 22, 4213-4227, https://doi.org/10.1175/2009JCLI2487.1.

Blakeslee, R., and W. Koshak, 2016: LIS on ISS: Expanded global coverage and enhanced applications. The Earth Observer, Vol. 28, No. 3, EOS Project Science Office, Greenbelt, MD, 4-14, https://eospso.gsfc.nasa.gov/sites/ default/files/eo_pdfs/May_June_2016_color\%20508.pdf.

Blanchard, D. O., and R. E. Lopez, 1985: Spatial patterns of convection in south Florida. Mon. Wea. Rev., 113, 1282-1299, https:// doi.org/10.1175/1520-0493(1985)113<1282:SPOCIS > 2.0.CO;2.

Bluestein, H. B., E. W. McCaul Jr., G. P. Byrd, and G. R. Woodall, 1988: Mobile sounding observations of a tornadic storm near the dryline: The Canadian, Texas storm of 7 May 1986. Mon. Wea. Rev., 116, 1790-1804, https://doi.org/10.1175/1520-0493(1988) 116<1790:MSOOAT>2.0.CO;2.

Boccippio, D. J., W. J. Koshak, and R. J. Blakeslee, 2002: Performance assessment of the Optical Transient Detector and Lightning Imaging Sensor. Part I: Predicted diurnal variability. J. Atmos. Oceanic Technol., 19, 1318-1332, https://doi.org/ 10.1175/1520-0426(2002)019<1318:PAOTOT>2.0.CO;2.

Bordoni, S., and B. Stevens, 2006: Principal component analysis of the summertime winds over the Gulf of California: A gulf surge index. Mon. Wea. Rev., 134, 3395-3414, https://doi.org/ 10.1175/MWR3253.1.

Brenner, I. S., 1974: A surge of maritime tropical air-Gulf of California to the southwestern United States. Mon. Wea. Rev., 102, 375-389, https://doi.org/10.1175/1520-0493(1974)102<0375: ASOMTA $>2.0 . \mathrm{CO} ; 2$.

Bringi, V. N., L. Liu, P. C. Kennedy, and V. Chandrasekar, 1996: Dual multiparameter radar observations of intense convective storms: The 24 June 1992 case study. Meteor. Atmos. Phys., 59, 3-31, https://doi.org/10.1007/BF01031999.

Brooks, H. E., C. A. Doswell III, and M. P. Kay, 2003: Climatological estimates of local daily tornado probability for the United States. Wea. Forecasting, 18, 626-640, https://doi.org/10.1175/ 1520-0434(2003)018<0626:CEOLDT > 2.0.CO;2.

Brown, R. G., and C. Zhang, 1997: Variability of midtropospheric moisture and its effect on cloud-top height distribution during TOGA COARE. J. Atmos. Sci., 54, 2760-2774, https://doi.org/ 10.1175/1520-0469(1997)054<2760:VOMMAI >2.0.CO;2.

Brubaker, K. L., D. Entekhabi, and P. S. Eagleson, 1993: Estimation of continental precipitation recycling. J. Climate, 6, 1077-1089, https://doi.org/10.1175/1520-0442(1993)006<1077: $\mathrm{EOCPR}>2.0 . \mathrm{CO} ; 2$.

Burpee, R. W., 1972: Origin and structure of easterly waves in lower troposphere of North Africa. J. Atmos. Sci., 29, 77-90, https://doi.org/10.1175/1520-0469(1972)029<0077: TOASOE $>2.0 . \mathrm{CO} ; 2$.

__ , and L. N. Lahiff, 1984: Area-average rainfall variations on sea-breeze days in south Florida. Mon. Wea. Rev., 112 520-534, https://doi.org/10.1175/1520-0493(1984)112<0520: AARVOS $>2.0$.CO;2.

Byers, H. R., and H. R. Rodebush, 1948: Causes of thunderstorms of the Florida Peninsula. J. Meteor., 5, 275-280, https://doi.org/ 10.1175/1520-0469(1948)005<0275:COTOTF $>2.0 . C O ; 2$
Carey, L. D., and S. A. Rutledge, 1996: A multiparameter radar case study of the microphysical and kinematic evolution of a lightning producing storm. J. Meteor. Atmos. Phys., 59, 33-64, https://doi.org/10.1007/BF01032000.

, W. A. Petersen, and S. A. Rutledge, 2003: Evolution of cloudto-ground lightning and storm structure in the Spencer, South Dakota, tornadic supercell of 30 May 1998. Mon. Wea. Rev., 131, 1811-1831, https://doi.org/10.1175//2566.1.

Carlson, T. N., 1969: Some remarks on African disturbances and their progress over tropical Atlantic. Mon. Wea. Rev., 97, 716-726, https://doi.org/10.1175/1520-0493(1969)097<0716: SROADA $>2.3 . \mathrm{CO} ; 2$.

- , and F. H. Ludlam, 1968: Conditions for the occurrence of severe local storms. Tellus, 20, 203-226, https://doi.org/ 10.3402/tellusa.v20i2.10002.

— S. G. Benjamin, and G. S. Forbes, 1983: Elevated mixed layers in the regional severe storm environment: Conceptual model and case studies. Mon. Wea. Rev., 111, 1453-1474, https://doi.org/ 10.1175/1520-0493(1983)111<1453:EMLITR > 2.0.CO;2.

Cecil, D. J., 2009: Passive microwave brightness temperatures as proxies for hailstorms. J. Appl. Meteor. Climatol., 48, 12811286, https://doi.org/10.1175/2009JAMC2125.1.

— , and C. B. Blankenship, 2012: Toward a global climatology of severe hailstorms as estimated by satellite passive microwave imagers. J. Climate, 25, 687-703, https://doi.org/10.1175/JCLID-11-00130.1.

, S. J. Goodman, D. J. Boccippio, E. J. Zipser, and S. W. Nesbitt, 2005: Three years of TRMM precipitation features. Part I: Radar, radiometric, and lightning characteristics. Mon. Wea. Rev., 133, 543-566, https://doi.org/10.1175/MWR-2876.1. , D. E. Buechler, and R. J. Blakeslee, 2015: TRMM LIS climatology of thunderstorm occurrence and conditional lightning flash rates. J. Climate, 28, 6536-6547, https://doi.org/ 10.1175/JCLI-D-15-0124.1.

Cetrone, J., and R. A. Houze, 2011: Leading and trailing anvil clouds of West African squall lines. J. Atmos. Sci., 68, 11141123, https://doi.org/10.1175/2011JAS3580.1.

Chaggar, T. S., 1977: Geographical distribution of monthly and annual mean frequency of thunderstorm days over eastern Africa. East African Meteorological Department Tech. Memo. 26, 22 pp.

Chaves, R. R., and I. F. Cavalcanti, 2001: Atmospheric circulation features associated with rainfall variability over southern northeast Brazil. Mon. Wea. Rev., 129, 2614-2626, https://doi.org/ 10.1175/1520-0493(2001)129<2614:ACFAWR > 2.0.CO;2.

Christian, H. J., and Coauthors, 2003: Frequency and distribution of lightning as observed from space by the Optical Transient Detector. J. Geophys. Res., 108, 4005, https://doi.org/10.1029/ 2002JD002347.

Cotton, W. R., R. L. George, P. J. Wetzel, and R. L. McAnelly, 1983: A long-lived mesoscale convective complex. Part I: The mountain-generated component. Mon. Wea. Rev., 111, 1893-1918, https://doi.org/10.1175/1520-0493(1983)111<1893: ALLMCC $>2.0 . \mathrm{CO} ; 2$.

Curran, E. B., R. L. Holle, and R. E. López, 2000: Lightning casualties and damages in the United States from 1959 to 1994. J. Climate, 13, 3448-3464, https://doi.org/10.1175/15200442(2000)013<3448:LCADIT>2.0.CO;2.

Dahl, J. M., H. Höller, and U. Schumann, 2011: Modeling the flash rate of thunderstorms. Part I: Framework. Mon. Wea. Rev., 139, 3093-3111, https://doi.org/10.1175/MWR-D-10-05031.1.

Dee, D. P., and Coauthors, 2011: The ERA-Interim reanalysis: Configuration and performance of the data assimilation 
system. Quart. J. Roy. Meteor. Soc., 137, 553-597, https:// doi.org/10.1002/qj.828.

Deierling, W., and W. A. Petersen, 2008: Total lightning activity as an indicator of updraft characteristics. J. Geophys. Res., 113, D16210, https://doi.org/10.1029/2007JD009598.

—,- J. Latham, S. Ellis, and H. J. Christian, 2008: The relationship between lightning activity and ice fluxes in thunderstorms. J. Geophys. Res., 113, D15210, https://doi.org/ 10.1029/2007JD009700.

Diaz, L., M. Martinez, J. Ramírez, and J. Rodriguez, 2009: Actualización de la actividad de rayos en Venezuela, empleando la información del proyecto satelital de la NASA. Congreso Venezolano de Redes y Energía Eléctrica, Porlamar, Venezuela, Comité Nacional Venezolano de CIGRÉ, B2-223.

Doswell, C. A., III, 1984: A kinematic analysis of frontogenesis associated with a nondivergent vortex. J. Atmos. Sci., 41, 1242-1248, https://doi.org/10.1175/1520-0469(1984)041<1242: AKAOFA $>2.0 . \mathrm{CO} ; 2$.

_- 2001: Severe convective storms-An overview. Severe Convective Storms, Meteor. Monogr., No. 50, Amer. Meteor. Soc., 1-26.

— , H. E. Brooks, and R. A. Maddox, 1996: Flash flood forecasting: An ingredients-based methodology. Wea. Forecasting, 11, 560-581, https://doi.org/10.1175/1520-0434(1996)011<0560: FFFAIB $>2.0 . \mathrm{CO} ; 2$.

Douglas, M. W., R. Maddox, K. Howard, and S. Reyes, 1993: The Mexican monsoon. J. Climate, 6, 1665-1677, https://doi.org/ 10.1175/1520-0442(1993)006<1665:TMM > 2.0.CO;2.

Durán-Quesada, A. M., M. Reboita, and L. Gimeno, 2012: Precipitation in tropical America and the associated sources of moisture: A short review. Hydrol. Sci. J., 57, 612-624, https:// doi.org/10.1080/02626667.2012.673723.

Durkee, J. D., and T. L. Mote, 2009: A climatology of warm-season mesoscale convective complexes in subtropical South America. Int. J. Climatol., 30, 418-431, https://doi.org/10.1002/joc.1893.

Finch, Z. O., and R. H. Johnson, 2010: Observational analysis of an upper-level inverted trough during the 2004 North American monsoon experiment. Mon. Wea. Rev., 138, 3540-3555, https:// doi.org/10.1175/2010MWR3369.1.

Fink, A. H., and A. Reiner, 2003: Spatiotemporal variability of the relation between African easterly waves and West African squall lines in 1998 and 1999. J. Geophys. Res., 108, 4332, https://doi.org/10.1029/2002JD002816.

Finney, D. L., R. M. Doherty, O. Wild, H. Huntrieser, H. C. Pumphrey, and A. M. Blyth, 2014: Using cloud ice flux to parametrise large-scale lightning. Atmos. Chem. Phys., 14, 12 665-12 682, https://doi.org/10.5194/acp-14-12665-2014.

Fujita, T., 1958: Structure and movement of a dry front. Bull. Amer. Meteor. Soc., 39, 574-582, https://doi.org/10.1175/1520-047739.11.574.

Fulks, J. R., 1951: The instability line. Compendium of Meteorology, T. F. Malone, Ed., Amer. Meteor. Soc., 647-652.

Gallo, K., T. Smith, K. Jungbluth, and P. Schumacher, 2012: Hail swaths observed from satellite data and their relation to radar and surface-based observations: A case study from Iowa in 2009. Wea. Forecasting, 27, 796-802, https://doi.org/10.1175/ WAF-D-11-00118.1.

Glass, F. H., D. L. Ferry, J. T. Moore, and S. M. Nolan, 1995: Characteristics of heavy convective rainfall events across the mid-Mississippi valley during the warm season: Meteorological conditions and a conceptual model. Preprints, 14th Conf. on Weather Analysis and Forecasting, Dallas, TX, Amer. Meteor. Soc., 34-41.
Green, C. R., and W. D. Sellers, Eds., 1964: Arizona Climate. University of Arizona Press, 503 pp.

Guy, N., and S. A. Rutledge, 2012: Regional comparison of West African convective characteristics: A TRMM-based climatology. Quart. J. Roy. Meteor. Soc., 138, 1179-1195, https:// doi.org/10.1002/qj.1865.

Hales, J. E., 1972: Surges of maritime tropical air northward over the Gulf of California. Mon. Wea. Rev., 100, 298-306, https://doi.org/ 10.1175/1520-0493(1972)100<0298:SOMTAN>2.3.CO;2.

Hane, C. E., H. B. Bluestein, T. M. Crawford, M. E. Baldwin, and R. M. Rabin, 1997: Severe thunderstorm development in relation to along-dryline variability: A case study. Mon. Wea. Rev., 125, 231-251, https://doi.org/10.1175/1520-0493(1997) $125<0231$ :STDIRT $>2.0$. CO;2.

Higgins, R. W., Y. Yao, and X. L. Wang, 1997: Influence of the North American monsoon system on the U.S. summer precipitation regime. J. Climate, 10, 2600-2622, https://doi.org/ 10.1175/1520-0442(1997)010<2600:IOTNAM >2.0.CO;2.

Hoch, J., and P. Markowski, 2005: A climatology of springtime dryline position in the U.S. Great Plains region. J. Climate, $\mathbf{1 8}$, 2132-2137, https://doi.org/10.1175/JCLI3392.1.

Hou, A. Y., and Coauthors, 2014: The Global Precipitation Measurement mission. Bull. Amer. Meteor. Soc., 95, 701-722, https://doi.org/10.1175/BAMS-D-13-00164.1.

Houze, R. A., Jr., D. C. Wilton, and B. F. Smull, 2007: Monsoon convection in the Himalayan region as seen by the TRMM Precipitation Radar. Quart. J. Roy. Meteor. Soc., 133, 13891411, https://doi.org/10.1002/QJ.106.

— K. K. Rasmussen, M. D. Zuluaga, and S. R. Brodzik, 2015: The variable nature of convection in the tropics and subtropics: A legacy of 16 years of the tropical rainfall measuring mission satellite. Rev. Geophys., 53, 994-1021, https://doi.org/ 10.1002/2015RG000488.

Hubert, H., 1926: Nouvelles Études sur la Météorologie de l'Afrique Occidentale Française. Publications du Gouverneur Général de l'Afrique-Occidentale Française.

Jackson, B., S. E. Nicholson, and D. Klotter, 2009: Mesoscale convective systems over western equatorial Africa and their relationship to large-scale circulation. Mon. Wea. Rev., 137, 1272-1294, https://doi.org/10.1175/2008MWR2525.1.

Johns, R. H., 1982: A synoptic climatology of northwest flow severe weather outbreaks. Part I: Nature and significance. Mon. Wea. Rev., 110, 1653-1663, https://doi.org/10.1175/1520-0493(1982) $110<1653$ :ASCONF $>2.0 . \mathrm{CO} ; 2$.

_ Wea. Forecasting, 7, 588-612, https://doi.org/10.1175/15200434(1992)007<0588:SLSF>2.0.CO;2.

Johnson, R. H., P. E. Ciesielski, and J. A. Cotturone, 2001: Multiscale variability of the atmospheric mixed layer over the western Pacific warm pool. J. Atmos. Sci., 58, 2729-2750, https://doi.org/ 10.1175/1520-0469(2001)058<2729:MVOTAM >2.0.CO;2.

,-- , B. D. McNoldy, P. J. Rogers, and R. K. Taft, 2007: Multiscale variability of the flow during the North American Monsoon Experiment. J. Climate, 20, 1628-1648, https:// doi.org/10.1175/JCLI4087.1.

Kummerow, C., W. Barnes, T. Kozu, J. Shiue, and J. Simpson, 1998: The Tropical Rainfall Measuring Mission (TRMM) sensor package. J. Atmos. Oceanic Technol., 15, 809-817, https://doi.org/10.1175/1520-0426(1998)015<0809:TTRMMT> 2.0.CO;2.

Lafore, J.-P., and Coauthors, 2011: Progress in understanding of weather systems in West Africa. Atmos. Sci. Lett., 12, 7-12, https://doi.org/10.1002/asl.335. 
Lal, D. M., and S. D. Pawar, 2009: Relationship between rainfall and lightning over central Indian region in monsoon and premonsoon seasons. Atmos. Res., 92, 402-410, https://doi.org/ 10.1016/j.atmosres.2008.12.009.

Lang, T. J., and S. A. Rutledge, 2002: Relationships between convective storm kinematics, precipitation, and lightning. Mon. Wea. Rev., 130, 2492-2506, https://doi.org/10.1175/15200493(2002)130<2492:RBCSKP $>2.0 . C O ; 2$.

Liu, C., and E. J. Zipser, 2005: Global distribution of convection penetrating the tropical tropopause. J. Geophys. Res., 110, D23104, https://doi.org/10.1029/2005JD006063.

_ , and — 2013: Regional variation of morphology of organized convection in the tropics and subtropics. J. Geophys. Res. Atmos., 118, 453-466, https://doi.org/10.1029/2012JD018409.

— , and - 2015: The global distribution of largest, deepest, and most intense precipitation systems. Geophys. Res. Lett., 42, 3591-3595, https://doi.org/10.1002/2015GL063776.

,-- D. J. Cecil, S. W. Nesbitt, and S. Sherwood, 2008: A cloud and precipitation feature database from nine years of TRMM observations. J. Appl. Meteor. Climatol., 47, 27122728, https://doi.org/10.1175/2008JAMC1890.1.

— D. J. Cecil, E. J. Zipser, K. Kronfeld, and R. Robertson, 2012: Relationships between lightning flash rates and radar reflectivity vertical structures in thunderstorms over the tropics and subtropics. J. Geophys. Res., 117, D06212, https://doi.org/ 10.1029/2011JD017123.

Liu, N., and C. Liu, 2016: Global distribution of deep convection reaching tropopause in 1 year GPM observations. J. Geophys. Res. Atmos., 121, 3824-3842, https://doi.org/ 10.1002/2015JD024430.

$\ldots$, and _ 2018: Synoptic environments and characteristics of convection reaching the tropopause over northeast China. Mon. Wea. Rev., 146, 745-759, https://doi.org/10.1175/MWRD-17-0245.1.

Lopez, M. E., 1966: Cloud seeding trials in the rainy belt of western Colombia. Water Resour. Res., 2, 811-823, https://doi.org/ 10.1029/WR002i004p00811.

MacGorman, D. R., and D. W. Burgess, 1994: Positive cloud-toground lightning in tornadic storms and hailstorms. Mon. Wea. Rev., 122, 1671-1697, https://doi.org/10.1175/1520-0493(1994) 122<1671:PCTGLI>2.0.CO;2.

Maddox, R. A., 1976: An evaluation of tornado proximity wind and stability data. Mon. Wea. Rev., 104, 133-142, https://doi.org/ 10.1175/1520-0493(1976)104<0133:AEOTPW>2.0.CO;2.

Magaña, V., J. A. Amador, and S. Medina, 1999: The midsummer drought over Mexico and Central America. J. Climate, 12, 1577-1588, https://doi.org/10.1175/1520-0442(1999)012<1577: TMDOMA $>2.0 . \mathrm{CO} ; 2$.

Mapes, B. E., T. T. Warner, M. Xu, and A. J. Negri, 2003: Diurnal patterns of rainfall in northwestern South America. Part I: Observations and context. Mon. Wea. Rev., 131, 799-812, https:// doi.org/10.1175/1520-0493(2003)131<0799:DPORIN>2.0.CO;2.

Marengo, J. A., W. R. Soares, C. Saulo, and M. Nicolini, 2004: Climatology of the low level jet east of the Andes as derived from the NCEP-NCAR reanalyses: Characteristics and temporal variability. J. Climate, 17, 2261-2280, https://doi.org/ 10.1175/1520-0442(2004)017<2261:COTLJE >2.0.CO;2.

May, P. T., 1996: The organization of convection in the rainbands of Tropical Cyclone Laurence. Mon. Wea. Rev., 124, 807-815, https://doi.org/10.1175/1520-0493(1996)124<0807: TOOCIT $>2.0 . \mathrm{CO} ; 2$.

McCarthy, J., and S. E. Koch, 1982: The evolution of an Oklahoma dryline. Part I: A meso- and subsynoptic-scale analysis.
J. Atmos. Sci., 39, 225-236, https://doi.org/10.1175/15200469(1982)039<0225:TEOAOD > 2.0.CO;2.

McCollum, D., R. Maddox, and K. Howard, 1995: Case study of a severe mesoscale convective system in central Arizona. Wea. Forecasting, 10, 643-665, https://doi.org/10.1175/15200434(1995)010<0643:CSOASM>2.0.CO;2.

McNulty, R. P., 1978: On upper tropospheric kinematics and severe weather occurrence. Mon. Wea. Rev., 106, 662-672, https:// doi.org/10.1175/1520-0493(1978)106<0662:OUTKAS > 2.0.CO;2.

Medina, S., R. A. Houze Jr., A. Kumar, and D. Niyogi, 2010: Summer monsoon convection in the Himalayan region: Terrain and land cover effects. Quart. J. Roy. Meteor. Soc., 136, 593-616, https://doi.org/10.1002/qj.601.

Meijer, E., P. van Velthoven, D. Brunner, H. Huntrieser, and H. Kelder, 2001: Improvement and evaluation of the parameterisation of nitrogen oxide production by lightning. Phys. Chem. Earth, 26, 577-583, https://doi.org/10.1016/ s1464-1917(01)00050-2.

Mekonnen, A., C. D. Thorncroft, and A. R. Aiyyer, 2006: Analysis of convection and its association with African easterly waves. J. Climate, 19, 5405-5421, https://doi.org/10.1175/JCLI3920.1.

Miller, D., and J. M. Fritsch, 1991: Mesoscale convective complexes in the western Pacific region. Mon. Wea. Rev., 119, 2978-2992, https://doi.org/10.1175/1520-0493(1991)119<2978: MCCITW $>2.0 . C O ; 2$.

Miller, R., 1972: Notes on analysis and severe-storm forecasting procedures of the Air Force Global Weather Central. Air Weather Service Tech. Rep. 200, 190 pp.

Miller, S. T. K., B. D. Keim, R. W. Talbot, and H. Mao, 2003: Sea breeze: Structure, forecasting, and impacts. Rev. Geophys., $\mathbf{4 1}$, 1011, https://doi.org/10.1029/2003RG000124.

Mohr, K. I., and E. J. Zipser, 1996: Defining mesoscale convective systems by their $85-\mathrm{GHz}$ ice-scattering signatures. Bull. Amer. Meteor. Soc., 77, 1179-1189, https://doi.org/10.1175/15200477(1996)077<1179:DMCSBT>2.0.CO;2.

E. R. Toracinta, E. J. Zipser, and R. E. Orville, 1996: A comparison of WSR-88D reflectivities, SSM/I brightness temperatures, and lightning for mesoscale convective systems in Texas. Part II: SSM/I brightness temperatures and lightning. J. Appl. Meteor., 35, 919-931, https://doi.org/10.1175/15200450(1996)035<0919:ACOWRS > 2.0.CO;2.

Moore, J. T., F. H. Glass, C. E. Graves, S. M. Rochette, and M. J. Singer, 2003: The environment of warm-season elevated thunderstorms associated with heavy rainfall over the central United States. Wea. Forecasting, 18, 861-878, https://doi.org/ 10.1175/1520-0434(2003)018<0861:TEOWET >2.0.CO;2.

Mulholland, J. P., S. W. Nesbitt, R. J. Trapp, K. L. Rasmussen, and P. V. Salio, 2018: Convective storm life cycle and environments near the Sierras de Córdoba, Argentina. Mon. Wea. Rev., 146, 2541-2557, https://doi.org/10.1175/MWR-D-18-0081.1.

Murphey, H. V., R. M. Wakimoto, C. Flamant, and D. E. Kingsmill, 2006: Dryline on 19 June 2002 during IHOP. Part I: Airborne Doppler and LEANDRE II analyses of the thin line structure and convection initiation. Mon. Wea. Rev., 134, 406430, https://doi.org/10.1175/MWR3063.1.

Nascimento, E. L., and C. A. Doswell III, 2006: The need for an improved documentation of severe thunderstorms and tornadoes in South America. Symp. on the Challenges of Severe Convective Storms, Atlanta, GA, Amer. Meteor. Soc., P1.18, https://ams.confex.com/ams/Annual2006/techprogram/paper_ 102247.htm

Newman, A. J., and R. H. Johnson, 2012: Mechanisms for precipitation enhancement in a North American monsoon upper-tropospheric 
trough. J. Atmos. Sci., 69, 1775-1792, https://doi.org/10.1175/ JAS-D-11-0223.1.

Nicholls, M. E., R. A. Pielke, and W. R. Cotton, 1991: A twodimensional numerical investigation of the interaction between sea breezes and deep convection over the Florida Peninsula. Mon. Wea. Rev., 119, 298-323, https://doi.org/ 10.1175/1520-0493(1991)119<0298:ATDNIO>2.0.CO;2.

Nicholls, S. D., and K. I. Mohr, 2010: An analysis of the environments of intense convective systems in West Africa in 2003. Mon. Wea. Rev., 138, 3721-3739, https://doi.org/ 10.1175/2010MWR3321.1.

Nicholson, S. E., 1996: A review of climate dynamics and climate variability in eastern Africa. The Limnology, Climatology and Paleoclimatology of the East African Lakes, T. C. Johnson and E. O. Odada, Eds., Gordon and Breach, 25-56.

- 2009: A revised picture of the structure of the "monsoon" and land ITCZ over West Africa. Climate Dyn., 32, 1155-1171, https://doi.org/10.1007/s00382-008-0514-3.

_- 2018: The ITCZ and the seasonal cycle over equatorial Africa. Bull. Amer. Meteor. Soc., 99, 337-348, https://doi.org/ 10.1175/BAMS-D-16-0287.1.

Nieto Ferreira, R., T. M. Rickenbach, D. L. Herdies, and L. M. V. Carvalho, 2003: Variability of South American convective cloud systems and tropospheric circulation during January-March 1998 and 1999. Mon. Wea. Rev., 131, 961-973, https://doi.org/ 10.1175/1520-0493(2003)131<0961:VOSACC >2.0.CO;2.

Orville, R. E., and R. W. Henderson, 1986: Global distribution of midnight lightning: September 1977 to August 1978. Mon. Wea. Rev., 114, 2640-2653, https://doi.org/10.1175/1520-0493(1986) 114<2640:GDOMLS>2.0.CO;2.

Parker, D. J., C. D. Thorncroft, R. R. Burton, and A. DiongueNiang, 2005: Analysis of the African easterly jet, using aircraft observations from the JET2000 experiment. Quart. J. Roy. Meteor. Soc., 131, 1461-1482, https://doi.org/10.1256/qj.03.189.

Pessi, A. T., and S. Businger, 2009: Relationships among lightning, precipitation, and hydrometeor characteristics over the North Pacific Ocean. J. Appl. Meteor. Climatol., 48, 833-848, https:// doi.org/10.1175/2008JAMC1817.1.

Petersen, W. A., S. A. Rutledge, and R. E. Orville, 1996: Cloudto-ground lightning observations from TOGA COARE: Selected results and lightning location algorithms. Mon. Wea. Rev., 124, 602-620, https://doi.org/10.1175/1520-0493(1996) $124<0602:$ CTGLOF $>2.0$. CO;2.

- H. J. Christian, and S. A. Rutledge, 2005: TRMM observations of the global relationship between ice water content and lightning. Geophys. Res. Lett., 32, L14819, https://doi.org/ 10.1029/2005GL023236.

Peterson, R. E., 1983: The west Texas dryline: Occurrence and behavior. Preprints, 13th Conf. Severe Local Storms, Tulsa, OK, Amer. Meteor. Soc., J9-J11.

Pielke, R. A., A. Song, P. J. Michaels, W. A. Lyons, and R. W. Arritt, 1991: The predictability of sea-breeze generated thunderstorms. Atmósfera, 4, 65-78.

Pinto, O., and Coauthors, 2004: Thunderstorm and lightning characteristics associated with sprites in Brazil. Geophys. Res. Lett., 31, L13103, https://doi.org/10.1029/2004GL020264.

Poveda, G., and O. J. Mesa, 2000: On the existence of Lloró (the rainiest locality on Earth): Enhanced ocean-land-atmosphere interaction by a low-level jet. Geophys. Res. Lett., 27, 16751678, https://doi.org/10.1029/1999GL006091.

_ , P. R. Waylen, and R. S. Pulwarty, 2006: Annual and inter-annual variability of the present climate in northern South America and southern Mesoamerica. Palaeogeogr.
Palaeoclimatol. Palaeoecol., 234, 3-27, https://doi.org/10.1016/ j.palaeo.2005.10.031.

Price, C., and D. Rind, 1992: A simple lightning parameterization for calculating global lightning distributions. J. Geophys. Res., 97, 9919-9933, https://doi.org/10.1029/92JD00719.

_- Y. Yair, and M. Asfur, 2007: East African lightning as a precursor of Atlantic hurricane activity. Geophys. Res. Lett., 34, L09805, https://doi.org/10.1029/2006GL028884.

Qie, X., R. Toumi, and T. Yuan, 2003: Lightning activities on the Tibetan Plateau as observed by the Lightning Imaging Sensor. J. Geophys. Res., 108, 4551, https://doi.org/10.1029/ 2002JD003304.

_ - X. Wu, T. Yuan, J. Bian, and D. Lu, 2014: Comprehensive pattern of deep convective systems over the Tibetan PlateauSouth Asian monsoon region based on TRMM data. J. Climate, 27, 6612-6626, https://doi.org/10.1175/JCLI-D-14-00076.1.

Ranalkar, M., and H. Chaudhari, 2009: Seasonal variation of lightning activity over the Indian subcontinent. Meteor. Atmos. Phys., 104, 125-134, https://doi.org/10.1007/s00703-009-0026-7.

Rasmussen, K. L., and R. A. Houze Jr., 2011: Orogenic convection in subtropical South America as seen by the TRMM satellite. Mon. Wea. Rev., 139, 2399-2420, https://doi.org/10.1175/MWRD-10-05006.1.

— and - 2012: A flash-flooding storm at the steep edge of high terrain: Disaster in the Himalayas. Bull. Amer. Meteor. Soc., 93, 1713-1724, https://doi.org/10.1175/BAMS-D-11-00236.1.

— , and —, 2016: Convective initiation near the Andes in subtropical South America. Mon. Wea. Rev., 144, 2351-2374, https://doi.org/10.1175/MWR-D-15-0058.1.

— M. D. Zuluaga, and R. A. Houze Jr., 2014: Severe convection and lightning in subtropical South America. Geophys. Res. Lett., 41, 7359-7366, https://doi.org/10.1002/2014GL061767.

Reason, C. J., W. Landman, and W. Tennant, 2006: Seasonal to decadal prediction of southern African climate and its links with variability of the Atlantic Ocean. Bull. Amer. Meteor. Soc., 87, 941-956, https://doi.org/10.1175/BAMS-87-7-941.

Rhea, J. O., 1966: A study of thunderstorm formation along dry lines. J. Appl. Meteor., 5, 58-63, https://doi.org/10.1175/15200450(1966)005<0058:ASOTFA>2.0.CO;2.

Richter, H., and L. F. Bosart, 2002: The suppression of deep moist convection near the southern Great Plains dryline. Mon. Wea. Rev., 130, 1665-1691, https://doi.org/10.1175/1520-0493(2002) 130<1665:TSODMC $>2.0$. CO;2.

Roca, R., J. Lafore, C. Piriou, and J. Redelsperger, 2005: Extratropical dry-air intrusions into the West African monsoon midtroposphere: An important factor for the convective activity over the Sahel. J. Atmos. Sci., 62, 390-407, https://doi.org/10.1175/JAS-3366.1.

Rockwood, A. A., and R. A. Maddox, 1988: Mesoscale and synoptic interactions leading to intense convection: The case of 7 June 1982. Wea. Forecasting, 3, 51-68, https://doi.org/ 10.1175/1520-0434(1988)003<0051:MASSIL > 2.0.CO;2.

Romatschke, U., and R. A. Houze Jr., 2010: Extreme summer convection in South America. J. Climate, 23, 3761-3791, https://doi.org/10.1175/2010JCLI3465.1.

—_, and —_, 2011: Characteristics of precipitating convective systems in the premonsoon season of South Asia. J. Hydrometeor., 12, 157-180, https://doi.org/10.1175/ 2010JHM1311.1.

_, S. Medina, and R. A. Houze Jr., 2010: Regional, seasonal, and diurnal variations of extreme convection in the South Asian region. J. Climate, 23, 419-439, https://doi.org/10.1175/ 2009JCLI3140.1. 
Rosenfeld, D., W. L. Woodley, T. W. Krauss, and V. Makitov, 2006: Aircraft microphysical documentation from cloud base to anvils of hailstorm feeder clouds in Argentina. J. Appl. Meteor. Climatol., 45, 1261-1281, https://doi.org/10.1175/JAM2403.1.

Said, R. K., M. B. Cohen, and U. S. Inan, 2013: Highly intense lightning over the oceans: Estimated peak currents from global GLD360 observations. J. Geophys. Res. Atmos., 118, 6905-6915, https://doi.org/10.1002/JGRD.50508.

Sakamoto, M. S., T. Ambrizzi, and G. Poveda, 2011: Moisture sources and life cycle of convective systems over western Colombia. Adv. Meteor., 2011, 890759, https://doi.org/10.1155/ 2011/890759.

Salio, P., M. Nicolini, and E. J. Zipser, 2007: Mesoscale convective systems over southeastern South America and their relationship with the South American low-level jet. Mon. Wea. Rev., 135, 1290-1309, https://doi.org/10.1175/MWR3305.1.

Savenije, H. H. G., 1995: New definitions of moisture recycling and relation with land-use changes in the Sahel. J. Hydrol., 167, 57 78, https://doi.org/10.1016/0022-1694(94)02632-L.

Schaefer, J. T., 1974: The life cycle of the dryline. J. Appl. Meteor., 13, 444-449, https://doi.org/10.1175/1520-0450(1974) $013<0444$ :TLCOTD $>2.0$. CO; 2 .

Schoenberg Ferrier, B., J. Simpson, and W.-K. Tao, 1996: Factors responsible for precipitation efficiencies in midlatitude and tropical squall simulations. Mon. Wea. Rev., 124, 2100-2125, https:// doi.org/10.1175/1520-0493(1996)124<2100:FRFPEI>2.0.CO;2.

Schultz, D. M., C. C. Weiss, and P. M. Hoffman, 2007: The synoptic regulation of dryline intensity. Mon. Wea. Rev., 135, 16991709, https://doi.org/10.1175/MWR3376.1.

Schulz, W., K. Cummins, G. Diendorfer, and M. Dorninger, 2005: Cloud-to-ground lightning in Austria: A 10-year study using data from a lightning location system. J. Geophys. Res., 110, D09101, https://doi.org/10.1029/2004JD005332.

Schumacher, R. S., and R. H. Johnson, 2005: Organization and environmental properties of extreme-rain-producing mesoscale convective systems. Mon. Wea. Rev., 133, 961-976, https://doi.org/10.1175/MWR2899.1.

Seluchi, M., and J. Marengo, 2000: Tropical-midlatitude exchange of air masses during summer and winter in South America: Climatic aspects and examples of intense events. Int. J. Climatol., 20, 1167-1190, https://doi.org/10.1002/10970088(200008)20:10<1167::AID-JOC526>3.0.CO;2-T.

Shaw, B. L., R. A. Pielke, and C. L. Ziegler, 1997: A threedimensional numerical simulation of a Great Plains dryline. Mon. Wea. Rev., 125, 1489-1506, https://doi.org/10.1175/15200493(1997)125<1489:ATDNSO > 2.0.CO;2.

Simpson, J. E., D. A. Mansfield, and J. R. Milford, 1977: Inland penetration of sea-breeze fronts. Quart. J. Roy. Meteor. Soc., 103, 47-76, https://doi.org/10.1002/qj.49710343504.

Spencer, R. W., and D. A. Santek, 1985: Measuring the global distribution of intense convection over land with passive microwave radiometry. J. Climate Appl. Meteor., 24 860-864, https://doi.org/10.1175/1520-0450(1985)024<0860: MTGDOI $>2.0 . \mathrm{CO} ; 2$

Steenburgh, W. J., and C. F. Mass, 1994: The structure and evolution of a simulated Rocky Mountains lee trough. Mon. Wea. Rev., 122, 2740-2761, https://doi.org/10.1175/1520-0493(1994) $122<2740$ :TSAEOA $>2.0 . \mathrm{CO} ; 2$

Stensrud, D. J., 2013: Upscale effects of deep convection during the North American monsoon. J. Atmos. Sci., 70, 2681-2695, https://doi.org/10.1175/JAS-D-13-063.1.

_ , R. L. Gall, and M. K. Nordquist, 1997: Surges over the Gulf of California during the Mexican monsoon. Mon. Wea. Rev.,
125, 417-437, https://doi.org/10.1175/1520-0493(1997)125<0417: SOTGOC $>2.0 . \mathrm{CO} ; 2$.

Takemi, T., 2007: A sensitivity of squall-line intensity to environmental static stability under various shear and moisture conditions. Atmos. Res., 84, 374-389, https://doi.org/10.1016/ j.atmosres.2006.10.001.

Tao, W.-K., X. Li, A. Khain, T. Matsui, S. Lang, and J. Simpson, 2007: Role of atmospheric aerosol concentration on deep convective precipitation: Cloud-resolving model simulations. J. Geophys. Res., 112, D24S18, https://doi.org/10.1029/2007JD008728.

Taszarek, M., B. Czernecki, and A. Kozioł, 2015: A cloud-toground lightning climatology for Poland. Mon. Wea. Rev., 143, 4285-4304, https://doi.org/10.1175/MWR-D-15-0206.1.

Taylor, C. M., P. P. Harris, and D. J. Parker, 2010: Impact of soil moisture on the development of a Sahelian mesoscale convective system: A case-study from the AMMA special observing period. Quart. J. Roy. Meteor. Soc., 136, 456-470, https://doi.org/10.1002/qj.465.

Tetzlaff, G., and M. Peters, 1988: A composite study of early summer squall lines and their environment over West Africa. Meteor. Atmos. Phys., 38, 153-163, https://doi.org/10.1007/ BF01029779.

Thompson, R. L., and R. Edwards, 2000: An overview of environmental conditions and forecast implications of the 3 May 1999 tornado outbreak. Wea. Forecasting, 15, 682-699, https://doi.org/ 10.1175/1520-0434(2000)015<0682:AOOECA > 2.0.CO;2.

_ C. M. Mead, and R. Edwards, 2007: Effective storm-relative helicity and bulk shear in supercell thunderstorm environments. Wea. Forecasting, 22, 102-115, https://doi.org/10.1175/ WAF969.1.

Trenberth, K. E., 1999: Atmospheric moisture recycling: Role of advection and local evaporation. J. Climate, 12, 1368-1381, https:// doi.org/10.1175/1520-0442(1999)012<1368:AMRROA>2.0.CO;2.

Trier, S. B., C. A. Davis, D. A. Ahijevych, M. L. Weisman, and G. H. Bryan, 2006: Mechanisms supporting long-lived episodes of propagating nocturnal convection within a 7-day WRF model simulation. J. Atmos. Sci., 63, 2437-2461, https:// doi.org/10.1175/JAS3768.1.

Tuttle, J. D., and R. E. Carbone, 2004: Coherent regeneration and the role of water vapor and shear in a long-lived convective episode. Mon. Wea. Rev., 132, 192-208, https://doi.org/10.1175/ 1520-0493(2004)132<0192:CRATRO >2.0.CO;2.

Ushio, T., S. Heckman, D. J. Boccippio, and H. J. Christian, 2001: A survey of thunderstorm flash rates compared to cloud top height using TRMM satellite data. J. Geophys. Res., 106, 24 089-24 095, https://doi.org/10.1029/2001JD900233.

Uyeda, H., and Coauthors, 2001: Characteristics of convective clouds observed by a Doppler radar at Naqu on Tibetan Plateau during the GAME-Tibet IOP. J. Meteor. Soc. Japan, 79, 463-474, https://doi.org/10.2151/jmsj.79.463.

van Delden, A., 2001: The synoptic setting of thunderstorms in western Europe. Atmos. Res., 56, 89-110, https://doi.org/ 10.1016/S0169-8095(00)00092-2.

Velasco, I., and M. Frisch, 1987: Mesoscale convective complexes in the Americas. J. Geophys. Res., 92, 9591-9613, https:// doi.org/10.1029/JD092iD08p09591.

Vera, C., and Coauthors, 2006: Toward a unified view of the American monsoon systems. J. Climate, 19, 4977-5000, https:// doi.org/10.1175/JCLI3896.1.

Virts, K. S., and R. A. Houze, 2016: Seasonal and intraseasonal variability of mesoscale convective systems over the South Asian monsoon region. J. Atmos. Sci., 73, 4753-4774, https:// doi.org/10.1175/JAS-D-16-0022.1. 
Weisman, M. L., and J. B. Klemp, 1982: The dependence of numerically simulated convective storms on vertical wind shear and buoyancy. Mon. Wea. Rev., 110, 504-520, https://doi.org/ 10.1175/1520-0493(1982)110<0504:TDONSC > 2.0.CO;2.

- and R. Rotunno, 2000: The use of vertical wind shear versus helicity in interpreting supercell dynamics. J. Atmos. Sci., 57, 1452-1472, https://doi.org/10.1175/1520-0469(2000)057<1452: TUOVWS $>2.0 . \mathrm{CO} ; 2$.

Weiss, C. C., H. B. Bluestein, and A. L. Pazmany, 2006: Finescale radar observations of the 22 May 2002 dryline during the International $\mathrm{H}_{2} \mathrm{O}$ Project (IHOP). Mon. Wea. Rev., 134, $273-$ 293, https://doi.org/10.1175/MWR3068.1.

Weston, K. J., 1972: The dry-line of northern India and its role in cumulonimbus convection. Quart. J. Roy. Meteor. Soc., 98, 519-531, https://doi.org/10.1002/qj.49709841704.

Wiens, K. C., 2005: Kinematic, microphysical, and electrical structure and evolution of thunderstorms during the Severe Thunderstorm Electrification and Precipitation Study (STEPS). Ph.D. thesis, Colorado State University, 295 pp.

Wu, X., X. Qie, and T. Yuan, 2013: Regional distribution and diurnal variation of deep convective systems over the Asian monsoon region. Sci. China Earth Sci., 56, 843-854, https:// doi.org/10.1007/s11430-012-4551-8.

$-, \ldots, \ldots$, and J. Li, 2016: Meteorological regimes of the most intense convective systems along the southern Himalayan front. J. Climate, 29, 4383-4398, https://doi.org/10.1175/JCLI-D14-00835.1.

Xie, S., H. Xu, N. H. Saji, Y. Wang, and W. T. Liu, 2006: Role of narrow mountains in large-scale organization of Asian monsoon convection. J. Climate, 19, 3420-3429, https://doi.org/10.1175/ JCLI3777.1.

Xu, W., E. J. Zipser, C. Liu, and J. Jiang, 2010: On the relationships between lightning frequency and thundercloud parameters of regional precipitation systems. J. Geophys. Res., 115, D12203, https://doi.org/10.1029/2009JD013385.

Ziegler, C. L., and C. E. Hane, 1993: An observational study of the dryline. Mon. Wea. Rev., 121, 1134-1151, https://doi.org/ 10.1175/1520-0493(1993)121<1134:AOSOTD>2.0.CO;2.

— and E. N. Rasmussen, 1998: The initiation of moist convection at the dryline: Forecasting issues from a case study perspective. Wea. Forecasting, 13, 1106-1131, https://doi.org/ 10.1175/1520-0434(1998)013<1106:TIOMCA > 2.0.CO;2.

_- , T. J. Lee, and R. A. Pielke, 1997: Convective initiation at the dryline: A modeling study. Mon. Wea. Rev., 125, 1001-1026, https://doi.org/10.1175/1520-0493(1997)125<1001: CIATDA $>2.0 . \mathrm{CO} ; 2$.

Zipser, E. J., and K. R. Lutz, 1994: The vertical profile of radar reflectivity of convective cells: A strong indicator of storm intensity and lightning probability? Mon. Wea. Rev., 122, 1751-1759, https://doi.org/10.1175/1520-0493(1994)122<1751: TVPORR $>2.0 . \mathrm{CO} ; 2$.

- C. Liu, D. J. Cecil, S. W. Nesbitt, and D. P. Yorty, 2006: Where are the most intense thunderstorms on Earth? Bull. Amer. Meteor. Soc., 87, 1057-1072, https://doi.org/10.1175/ BAMS-87-8-1057.

Zuluaga, M., and R. A. Houze, 2015: Extreme convection of the near-equatorial Americas, Africa, and adjoining oceans as seen by TRMM. Mon. Wea. Rev., 143, 298-316, https://doi.org/ 10.1175/MWR-D-14-00109.1. 